\title{
Ultramafic geoecology of South and Southeast Asia
}

\author{
M. L. Galey ${ }^{1}$, A. van der Ent ${ }^{2,3}$, M. C. M. Iqbal ${ }^{4}$ and N. Rajakaruna ${ }^{5,6^{*}}$
}

\begin{abstract}
Globally, ultramafic outcrops are renowned for hosting floras with high levels of endemism, including plants with specialised adaptations such as nickel or manganese hyperaccumulation. Soils derived from ultramafic regoliths are generally nutrient-deficient, have major cation imbalances, and have concomitant high concentrations of potentially phytotoxic trace elements, especially nickel. The South and Southeast Asian region has the largest surface occurrences of ultramafic regoliths in the world, but the geoecology of these outcrops is still poorly studied despite severe conservation threats. Due to the paucity of systematic plant collections in many areas and the lack of georeferenced herbarium records and databased information, it is not possible to determine the distribution of species, levels of endemism, and the species most threatened. However, site-specific studies provide insights to the ultramafic geoecology of several locations in South and Southeast Asia. The geoecology of tropical ultramafic regions differs substantially from those in temperate regions in that the vegetation at lower elevations is generally tall forest with relatively low levels of endemism. On ultramafic mountaintops, where the combined forces of edaphic and climatic factors intersect, obligate ultramafic species and hyperendemics often occur. Forest clearing, agricultural development, mining, and climate change-related stressors have contributed to rapid and unprecedented loss of ultramafic-associated habitats in the region. The geoecology of the large ultramafic outcrops of Indonesia's Sulawesi, Obi and Halmahera, and many other smaller outcrops in South and Southeast Asia, remains largely unexplored, and should be prioritised for study and conservation.
\end{abstract}

Keywords: Adaptations, Conservation, Edaphic endemism, Edaphic flora, Extreme environments, Geobotany, Plantsoil relations, Serpentine vegetation, Ultramafic plants, Metal hyperaccumulators

\section{Background}

Ultramafic soils are weathered products of lithologies, such as peridotite and serpentinite bedrock, consisting predominantly of ferromagnesian silicate minerals (Cardace et al. 2014; Moores 2011). Ultramafic soils are generally deficient in essential plant mineral nutrients (phosphorus, potassium), have major cation imbalances (low calcium-to-magnesium molar ratios), and have high concentrations of certain phytotoxic elements, including nickel, cobalt and manganese (Brady et al. 2005; Kazakou et al. 2008; O'Dell and Rajakaruna 2011). Tropical ultramafic soils, unlike those in temperate regions (Alexander

\footnotetext{
*Correspondence: nrajakaruna@gmail.com

${ }^{5}$ Biological Sciences Department, California Polytechnic State University, San Luis Obispo, CA 93407, USA

Full list of author information is available at the end of the article
}

2009; Alexander and DuShey 2011), can be strongly weathered due to rainfall intensity and high temperature, and depending on elevation, can develop as laterites (e.g. Ferralsols) (Kruckeberg 2002; Mandal et al. 2015; van der Ent et al. 2013a; Vithanage et al. 2014).

Depauperate ultramafic soils may generate selective pressures promoting speciation and the evolution of ultramafic endemism (Anacker 2014; Kay et al. 2011; Rajakaruna 2004), often leading to distinctive plant communities worldwide (Anacker 2011; Brooks 1987). The biota of ultramafic soils has contributed greatly to the development of ecological and evolutionary theory (Harrison and Rajakaruna 2011; Strauss and Cacho 2013) and to the study of the genetics of adaptation and speciation (Brady et al. 2005; Palm and Van Volkenburgh 2014; von Wettberg and Wright 2011). Ultramafic floras are, however, threatened by deforestation, agricultural 
development, mining, and climate change-associated stressors (Boyd et al. 2009; Harrison et al. 2009; Rajakaruna and Boyd 2008; Vallano et al. 2012). These threats to ultramafic biota provide opportunities for conservation and restoration-oriented research (Elam et al. 1998; O'Dell and Claassen 2011; Weiss 1999; Whiting et al. 2004; Wolf 2001).

South and Southeast Asia contain several globally significant biodiversity hotspots (Mittermeier et al. 2005), including areas in Indo-Burma, Philippines, Sundaland (western half of the Indo-Malayan archipelago), and Western Ghats and Sri Lanka. The Borneo lowlands is the only ecoregion globally to surpass 10,000 plant species (Kier et al. 2005) and North Borneo is one of the top five biodiversity centres in the world (Barthlott et al. 2007). Despite South and Southeast Asia harboring several important biodiversity hotspots, the influence of edaphic factors on biodiversity is largely unknown (van der Ent et al. 2015a). Compared to research on ultramafic outcrops in temperate and Mediterranean regions (Alexander et al. 2007; Rajakaruna et al. 2009), ultramafic geoecology in this part of the world is also substantially understudied (Proctor 1992, 2003). In terms of tropical regions, most research related to ultramafic floras to date has focussed on New Caledonia (Isnard et al. 2016; Jaffré et al. 2010, 2013; Pillon et al. 2010; Pillon 2012). Although ultramafic outcrops of New Caledonia are of a similar latitude and general climate to South and Southeast Asia, the evolutionary histories of its flora and fauna are distinct. New Caledonia is on the east of the Lydekker's Line, which separates the eastern edge of Wallacea from the Australian Region (which lies on the Sahul Shelf), marking a distinct change in floristic affinities. In this review, we also exclude New Guinea (Indonesian West Papua and Papua New Guinea) for the same reason, but note that despite the concomitant occurrence of ultramafic outcrops and exceptionally high biodiversity, virtually nothing is known about the ultramafic geoecology of this island. Research on the floristics and ecology of the understudied ultramafics of South and Southeast Asia is critical to provide a comprehensive assessment of the ultramafic geoecology of tropical Asia.

This review examines the literature on the geoecology of ultramafic areas in South and Southeast Asia, covering India, Pakistan, and Sri Lanka to the west, Myanmar and Cambodia to the north, and Malaysia, Indonesia (excluding West Papua), and the Philippines to the east (Fig. 1; Table 1); all of which lie on the western side of Lydekker's line and share a similar climate. We focus on (i) soil-plant relations, including studies on floristic diversity, soilplant elemental relations, and soil microbes; (ii) ecological aspects, including studies on vegetation structure and composition and plant endemism; (iii) cross-kingdom interactions, including studies on herbivory, mycorrhizal associations, and invertebrate diversity; (iv) evolutionary aspects; (v) physiology and genetics; (vi) phytotechnologies; and finally, (vii) threats and conservation. We conclude the review by highlighting countries within South and Southeast Asia requiring further study, drawing attention to major gaps in knowledge.

\section{Soil-plant relations}

Ultramafic soils worldwide share a distinct suite of chemical and physical features (Rajakaruna et al. 2009); however, tropical ultramafic soils may differ in elemental content, moisture, organic matter content, and soil pedology (Kierczak et al. 2007; Vithanage et al. 2014), compared to those in temperate and Mediterranean regions (Alexander 2009; Alexander et al. 2007). Table 2 lists key soil properties of ultramafic soils from South and Southeast Asia, focusing on $\mathrm{pH}, \mathrm{Ca}: \mathrm{Mg}$ molar ratio, $\mathrm{Ni}$, $\mathrm{Cr}$, and the major nutrients, $\mathrm{P}$ and $\mathrm{K}$. Plants growing on ultramafic soils have to contend with a suite of edaphic stressors, including low nutrient content, high levels of phytotoxic elements, and, at times, water stress (Brady et al. 2005). Plants and soil microbes of ultramafic soils tolerate these edaphic stressors via efficient uptake of essential nutrients, and exclusion of, or conversely accumulation and localization of high concentrations, of certain phytotoxic elements, among other adaptations (see Palm and Van Volkenburgh 2014 for a discussion).

\section{Plant diversity and soil-plant elemental profiles}

In Sukinda, India, chromite mine spoils composed of ultramafic substrates have $\mathrm{Ni}$ ranging from 187 to $215 \mu \mathrm{g} \mathrm{g}^{-1}$ and Ca:Mg molar ratios of 1.69-2.27; from which, in total, 113 plant species belonging to 51 families have been recorded (Samantaray et al. 2001). Some species which colonize the substrate exhibit traits typical of plants adapted to ultramafic soils, including sclerophyllous and microphyllous leaves (Brady et al. 2005), but individual plants also show chlorosis, leaf curling, and necrosis.

On the Andaman Islands, India, ultramafic soils with high Ni concentrations (2700-10,100 $\mathrm{gg} \mathrm{g}^{-1}$ ) harbor eight $\mathrm{Ni}$ hyperaccumulator plant species belonging to eight different genera and seven different families (Datta et al. 2015). Of these, Dichapetalum gelonioides subsp. andamanicum (Dichapetalaceae) and Rinorea bengalensis (Violaceae) accumulated up to $30,000 \mu \mathrm{g} \mathrm{g}^{-1} \mathrm{Ni}$. There is substantial potential for using remote sensing tools to examine the vegetation communities on the ultramafics of the Andaman Islands, where the ultramafic outcrops are mostly inaccessible and the vegetation deserves more intensive exploration (Chaudhury et al. 2015). 

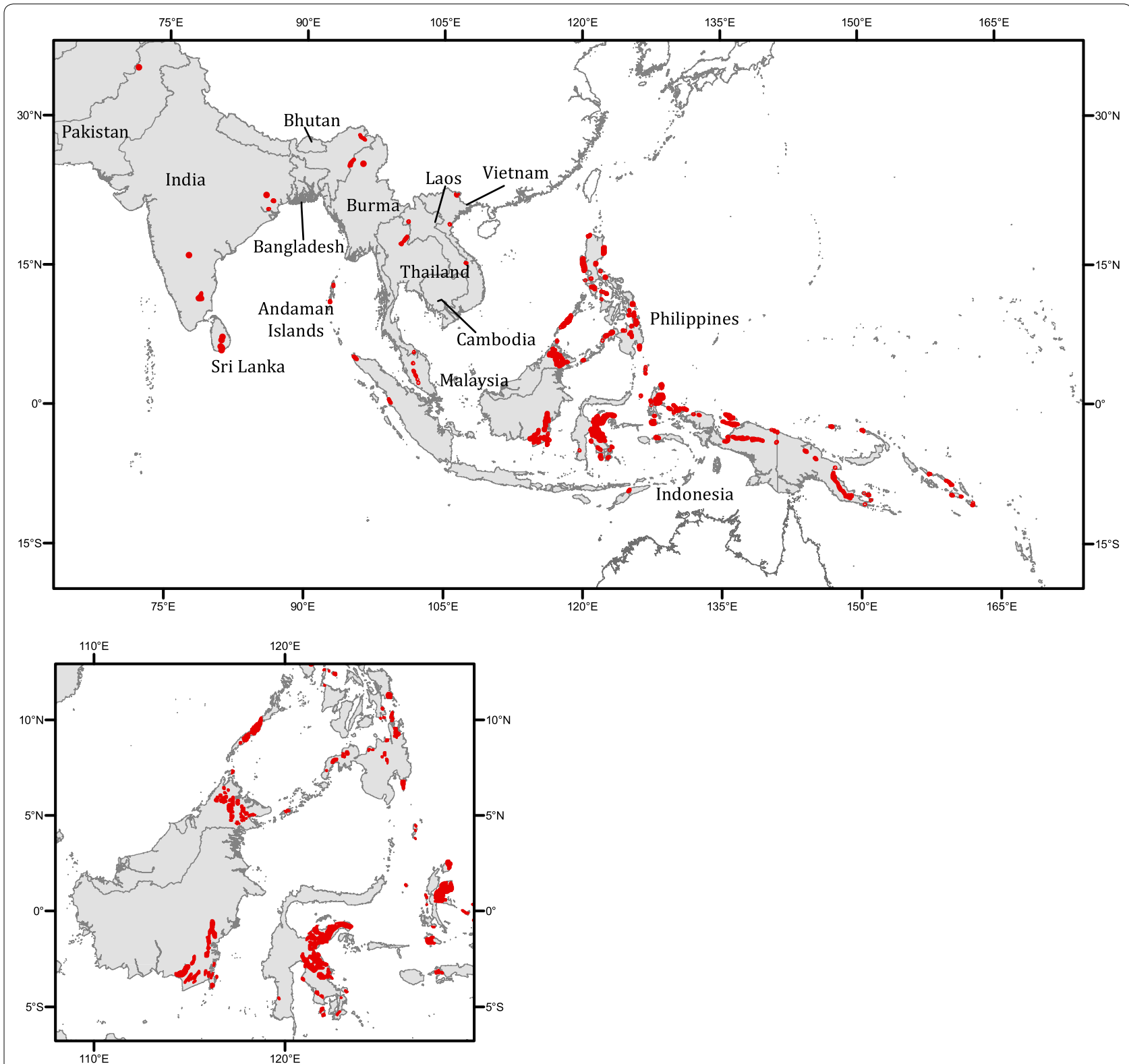

Fig. 1 Map of South and Southeast Asia showing the distribution of ultramafic outcrops in the region. Bottom inset is a more detailed outline of ultramafic outcrops in Borneo, Palawan, Mindanao, Sulawesi, and Halmahera. Not all regions of India have complete geologic surveys, and we were unable to locate precise information about ultramafic outcrops in Burma and Laos. The ultramafic outcrop location in Northern Thailand is approximate. The extent of each outcrop shown is not to scale [Figure compiled with data from Central Energy Resources Team (1999), Datta et al. (2015), Kfayatullah et al. (2001), Shi et al. (2012), Baker et al. (1992), Van der Ent et al. (2013a, 2015a), Tan and Khoo (1993), MacDonald and Barr (1984), Geological Survey of India, Geological and Mineral Maps of States and Regions (http://www.portal.gsi.gov.in/portal/page?_pageid=127,603606\&_ dad=portal\&_schema=PORTAL), and OneGeology Portal (http://portal.onegeology.org/OnegeologyGlobal/)]

In Northern Pakistan, the ultramafics of Mingora and Kabal in the Swat region include assemblages of serpentinite, green schist, talc-carbonate schist, and metabasalts in the Mingora-Shangla mélange zone (Shah et al. 2010). Relatively high accumulation of $\mathrm{Ni}$ and $\mathrm{Cr}$ has been recorded in the plant tissue of Indigofera gerardiana (Fabaceae), Saccharum griffithii (Poaceae), Lycopersicon esculentum (Solanaceae), and Chrysopogon zizanioides (Poaceae) growing in the Kot Parang Ghar mélange zone in the Bucha Area, Pakistan (Shah et al. 2010, 2014).

In Sri Lanka, ultramafic rocks occur along a Precambrian suture zone at the boundary of the Vijayan and Highland Series, metamorphic remnants of two ancient tectonic plates (Dissanayaka 1982; Munasinghe and 


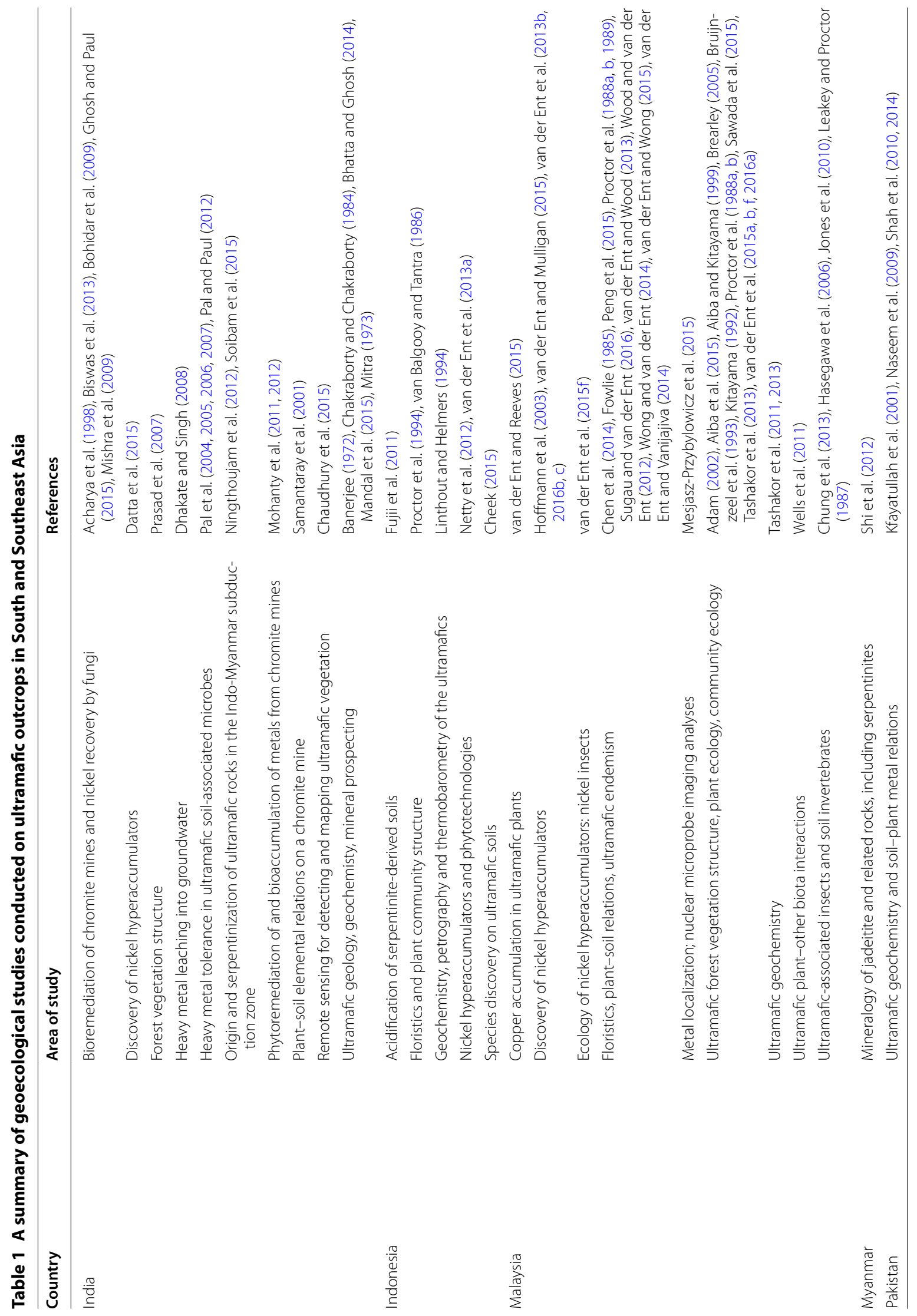




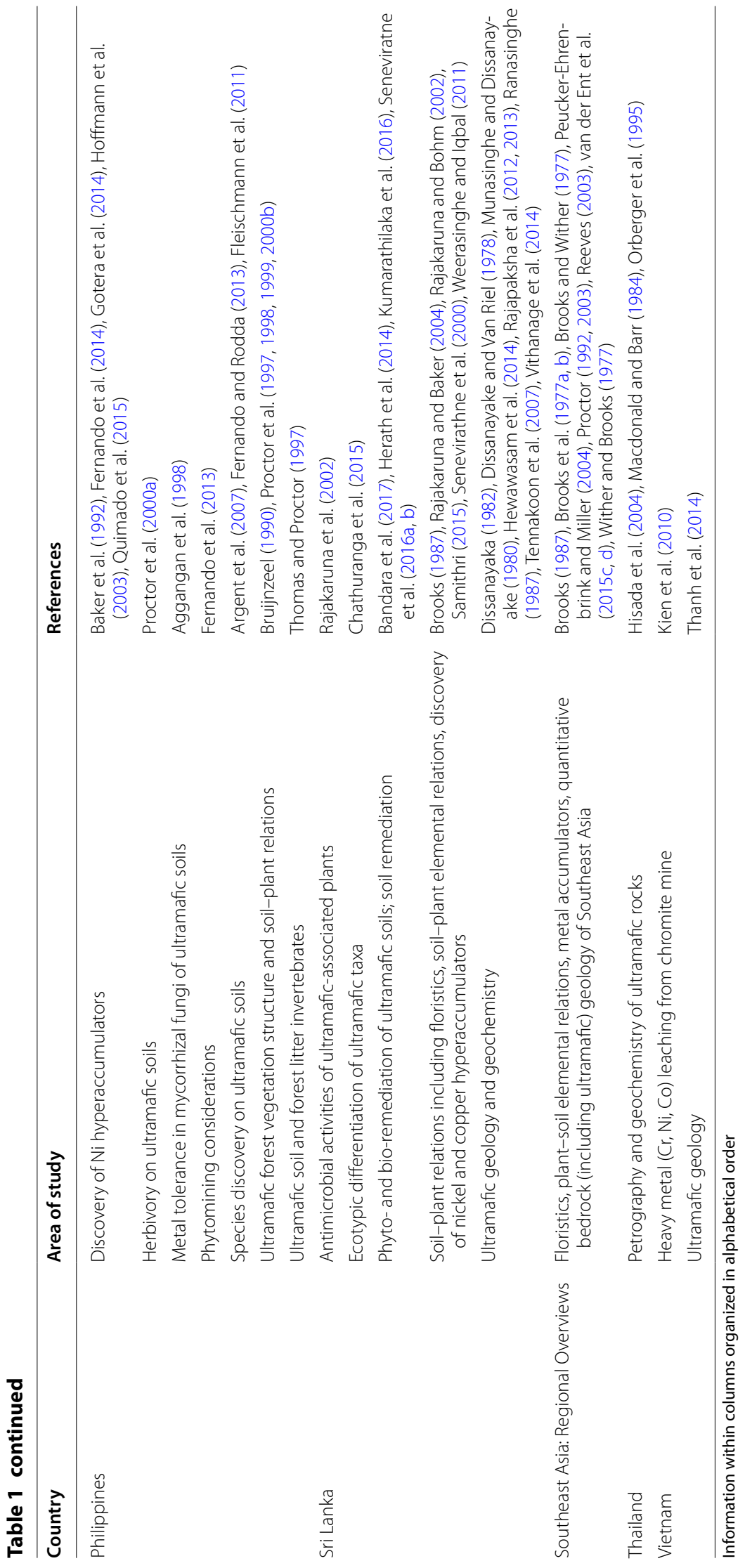




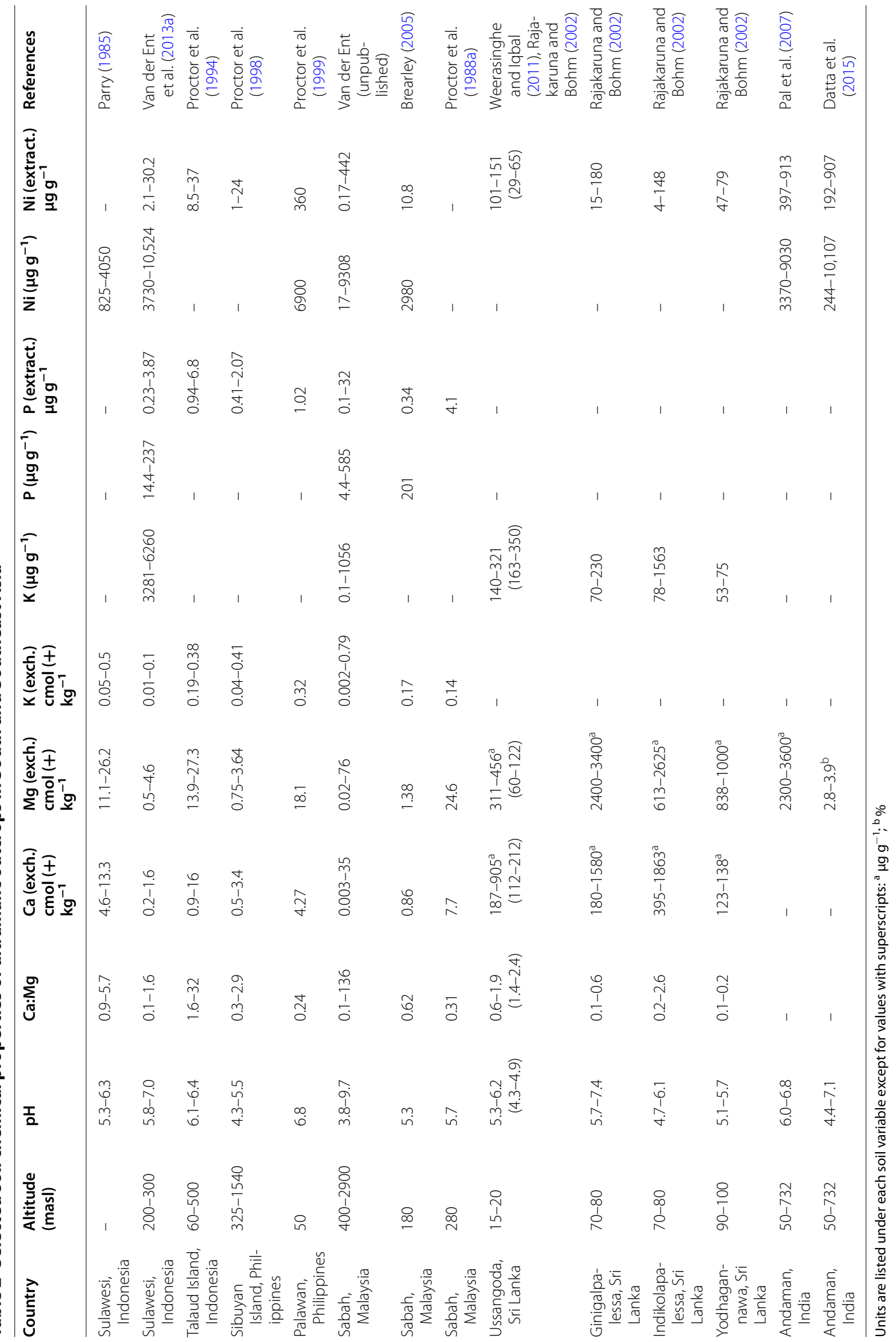


Dissanayake 1980). The geochemistry of these outcrops, particularly of Ussangoda along the southern coast, has been well-documented (Hewawasam et al. 2014; Rajapaksha et al. 2012, 2013; Tennakoon et al. 2007; Vithanage et al. 2014). The floristics of the ultramafic outcrops of Sri Lanka, especially of Ussangoda, have also received considerable attention (Brooks 1987; Rajakaruna and Baker 2004; Rajakaruna and Bohm 2002; Rajakaruna et al. 2002; Samithri 2015; Senevirathne et al. 2000; Weerasinghe and Iqbal 2011).

Research suggests that Sri Lanka's ultramafic flora is impoverished with respect to the total number of plant species and percent proportion of endemic species. To date, 67 plant species belonging to 61 genera and 30 families have been identified from Ussangoda (Samithri 2015). Combined with an additional 40 taxa reported from three other sites surveyed by Rajakaruna and Bohm (2002), the total ultramafic flora of Sri Lanka stands at a mere 107 species, compared to many-fold more documented from other sites in Southeast Asia (van der Ent et al. 2015a). Of the species documented from ultramafic soils, only Vernonia zeylanica (Asteraceae) is endemic to Sri Lanka (MOE 2012), although the taxon is not restricted to the substrate.

\section{Soil microbes}

Several recent studies, conducted in temperate and Mediterranean regions of the world, explore the roles microbes play in the ecology of ultramafic habitats as well as in the remediation of metal-contaminated soils (Batten et al. 2006; Ma et al. 2015; Schechter and Branco 2014). Although studies on microbial ecology of ultramafic soils in South and Southeast Asia are minimal, Pal et al. (2004, 2005, 2006, 2007) and Pal and Paul (2012) have carried out a series of studies on microbial diversity and ecology of ultramafic soils on the Andaman Islands, India. In one of these studies, Pal et al. (2005) compared physicochemical and microbial properties of ultramafic soils with those from adjacent non-ultramafic localities. The elemental profiles were characteristic of ultramafic soils, with high concentrations of $\mathrm{Mg}, \mathrm{Ni}, \mathrm{Cr}$, and $\mathrm{Co}$. Furthermore, the ultramafic soils showed low microbial density $\left(6.2-11.3 \times 10^{6}\right.$ colony forming unit/g soil) and activity (1.7-3.5 $\mu \mathrm{g}$ fluorescein/g dry soil/h) relative to non-ultramafic soils. The ultramafic-associated microbial population (including bacteria and fungi) was dominated by bacteria and was more resistant to metals than populations from non-ultramafic soils. Among the ultramafic isolates, 8 and 11 bacteria tolerated $>12.0 \mathrm{mM}$ $\mathrm{Ni}$ and $>16.0 \mathrm{mM} \mathrm{Cr}$, respectively, while six fungal isolates showed a minimum inhibitory concentration (MIC) value $>8.0 \mathrm{mM} \mathrm{Co}$. The ultramafic strains also showed co-resistance to $\mathrm{Cu}, \mathrm{Zn}$, and $\mathrm{Mn}$. Pal et al. (2007) also examined the soil microflora associated with the rhizosphere of two known Ni hyperaccumulators from the Andaman Islands, $R$. bengalensis and $D$. gelonioides subsp. andamanicum. Of the total 123 microbes (99 bacteria and 24 fungi) that were isolated, bacteria were more tolerant of Ni than fungi, showing their greater potential for Ni tolerance.

In a study focusing on medicinal qualities of wild-harvested plants, 32 plant species collected from ultramafic outcrops of Sri Lanka were screened for antimicrobial properties (Rajakaruna et al. 2002). Of these, 29 species belonging to 12 families proved effective against at least one microorganism. Photoactivity was also observed from extracts of 10 species belonging to 10 families. There was no observed correlation between trace element hyperaccumulation (Rajakaruna and Bohm 2002) and antimicrobial activity.

\section{Ecological aspects}

Ultramafic outcrops have long-provided model settings for studies on the ecology of plant species and plant communities. Studies range from those investigating aspects of the ecology of edaphically specialized plant populations and plant-plant interactions to those exploring factors and mechanisms driving the assembly of plant communities (see Harrison and Rajakaruna 2011). Compared to other regions of the world, ecological studies on ultramafics of South and Southeast Asia are mostly limited to those examining floristics, plant community structure, and edaphic-floristic associations.

\section{Vegetation structure and composition}

Mount Silam in Sabah, Malaysia, has been extensively studied, including the general floristics, forest structure, hydrology and chemical analysis of tree foliage and leaf litter (Proctor et al. 1988a, b, 1989; Bruijnzeel et al. 1993). The study plots on Mount Silam range from 280 to 870 masl in elevation, documenting a broad spectrum of vegetation changes with altitude. The site is extremely species-rich in terms of its tree flora, ranging between 19 species in a 0.04 -ha plot at 870 masl to 104 species in a 0.4-ha plot at 480 masl (Proctor 1992). Ultramafic-associated rainforests on Mount Guiting-Guiting, Sibuyan Island, Philippines (Proctor et al. 1998) and those of Mount Silam, Sabah (Proctor et al. 1988a, b) are similar in their soil features (Ni, Ca:Mg, and depth) and lack of stunted lowland forests. At these locations, small-statured forests are associated with higher elevations.

On Mount Bloomfield in the western Philippines (Palawan), Proctor et al. (1999) described a very different forest structure from those of Mount Silam and Mount Guiting-Guiting. The soil depths on Mount Bloomfield are much less compared to these other sites; Bruijnzeel 
(1990) suggested that drought in the shallow soils is a major cause of forest stunting on ultramafics, perhaps in association with fire (Proctor et al. 1997). Mount Bloomfield lacks tall forests and instead is characterised by trees less than $18 \mathrm{~m}$ tall. No statistical relationship could be established between tree height and soil chemistry, although Proctor et al. (1999) did find a direct proportional relationship between maximum tree height and soil water retention. The authors indirectly linked soil water to fire susceptibility in establishing the particular vegetation pattern on Mount Bloomfield, one that superficially resembles fire-dependent vegetation of $\mathrm{New}$ Caledonia.

Proctor et al. (2000a, b) compared vegetation on ultramafic soils to those on non-ultramafic (greywackederived) soils in Palawan and found that the species richness and diversity of ultramafic and greywacke sites were similar. However, the individual species and familial composition were rather different, with only members of the Saxifragaceae occurring on both ultramafic and greywacke soils. Trees on the serpentinized peridotite had a high proportion of microphyllous leaves, which is not a general feature of ultramafic forests in the region. Differences in water supply and fire frequencies, in combination with edaphic difference, may contribute to the distinct forests overlying these soils (Proctor et al. 1999, 2000a, b).

Sulawesi and Halmahera in Indonesia have 15,400 and $8000 \mathrm{~km}^{2}$ of ultramafic outcrops, respectively (van der Ent et al. 2013a). Lateritic soils overlaying the bedrock harbor both sclerophyllous ultramafic vegetation and more cryptic tropical rainforest, which are nonetheless inhabited by a high proportion of endemic flora. Proctor et al. (1994) examined the ultramafic soil-plant relations of Mount Piapi on Karakelong part of the Talaud Islands, North Sulawesi, Indonesia and reported that the short stature of the local vegetation is a result of low water-holding capacity of the soil, while the unusual species assemblage likely results from the soil chemistry typical of ultramafic soils. They also documented an undescribed Ni-hyperaccumulating species of Rinorea from their study site.

Kinabalu Park, Sabah, one of the world's most species-rich hotspots with more than 5000 plant species recorded in an area of just $1200 \mathrm{~km}^{2}$, is also home to extensive ultramafic exposures (van der Ent et al. 2014). Plant diversity on ultramafics of the Park decreases with elevation, with a mid-elevation (circum 1500 masl) 'hump' occurring for some plant groups (Orchidaceae, Pteridophytes) resulting from the presence of cloud forests (van der Ent et al. 2016a). Six main vegetation classes with associated soil types are described by van der Ent et al. (2016a), including Sub-Alpine Scrub and Graminoid Scrub, both associated with Hypermagnesic Cambisols ('hypermagnesian soils'), Montane Cloud Forest, associated with Cambisols often with accumulation of humus, Mixed Dipterocarp Forest, associated with deep Ferralsols ('laterites'), and Pioneer Casuarina Scrub and Mature Mixed Casuarina Forest, both associated with Hypermagnesic Leptosols. The 'adverse' soil chemistry exacerbates vegetation stunting but no clear correlation between elevation, soil chemistry and plant diversity was found, as some of the most 'adverse' soils on the summit of the entirely ultramafic Mount Tambuyukon (2359-2534 masl) had up to 132 species per $250 \mathrm{~m}^{2}$ (van der Ent et al. 2016a).

Samithri (2015) examined the vegetation community composition and patterns at Ussangoda, Sri Lanka's most intensively studied ultramafic outcrop. She found a higher diversity of plant species in 'forest islands' compared to the extensive 'plains' characterizing the site (Fig. 2c). Although the plains make up over $90 \%$ of the outcrop area, they only harbor 18 herbaceous species belonging to 17 genera and 11 families compared to 49 tree, shrub, herb and climber species belonging to 44 genera and 27 families found in the 'forest islands.' Although the soil chemical features did not differ significantly between sites on the 'plains' versus those in the 'forest islands,' soil features such as depth and resulting water holding capacity in 'forest islands' may favor the growth of a wide range of species than on the exposed and shallow soils of the 'plains.'

Studies on bryophytes, lichens, and epiphytes on ultramafic outcrops are sparse worldwide (but see Boyd et al. 2009; Briscoe et al. 2009; Favero-Longo et al. 2004; Rajakaruna et al. 2012). In South and Southeast Asia, such studies are mostly non-existent. However, one study from the Philippines (Proctor et al. 2000b) documents epiphytic plants on trees of ultramafic and adjacent greywacke soils. The trees on the greywacke had fewer lianas and much less bole bryophyte cover than those on the serpentinized peridotite. Forty-one percent of trees on peridotite had $>10 \%$ bryophyte cover, while none of the trees on greywacke soils had $>10 \%$ bryophyte cover. The greywacke soils also hosted significantly higher densities of ferns, Cyperaceae spp., rattans (Arecaceae: Calamoideae), and Pandanaceae spp. compared to ultramafic soils, while ultramafic soils harbored significantly more herbaceous and bamboo (Poaceae: Bambusoideae) species. Floristic differences between the sites were attributed to differences in geochemistry, hydrology, and fire-frequencies (Proctor et al. 1999, 2000b). 

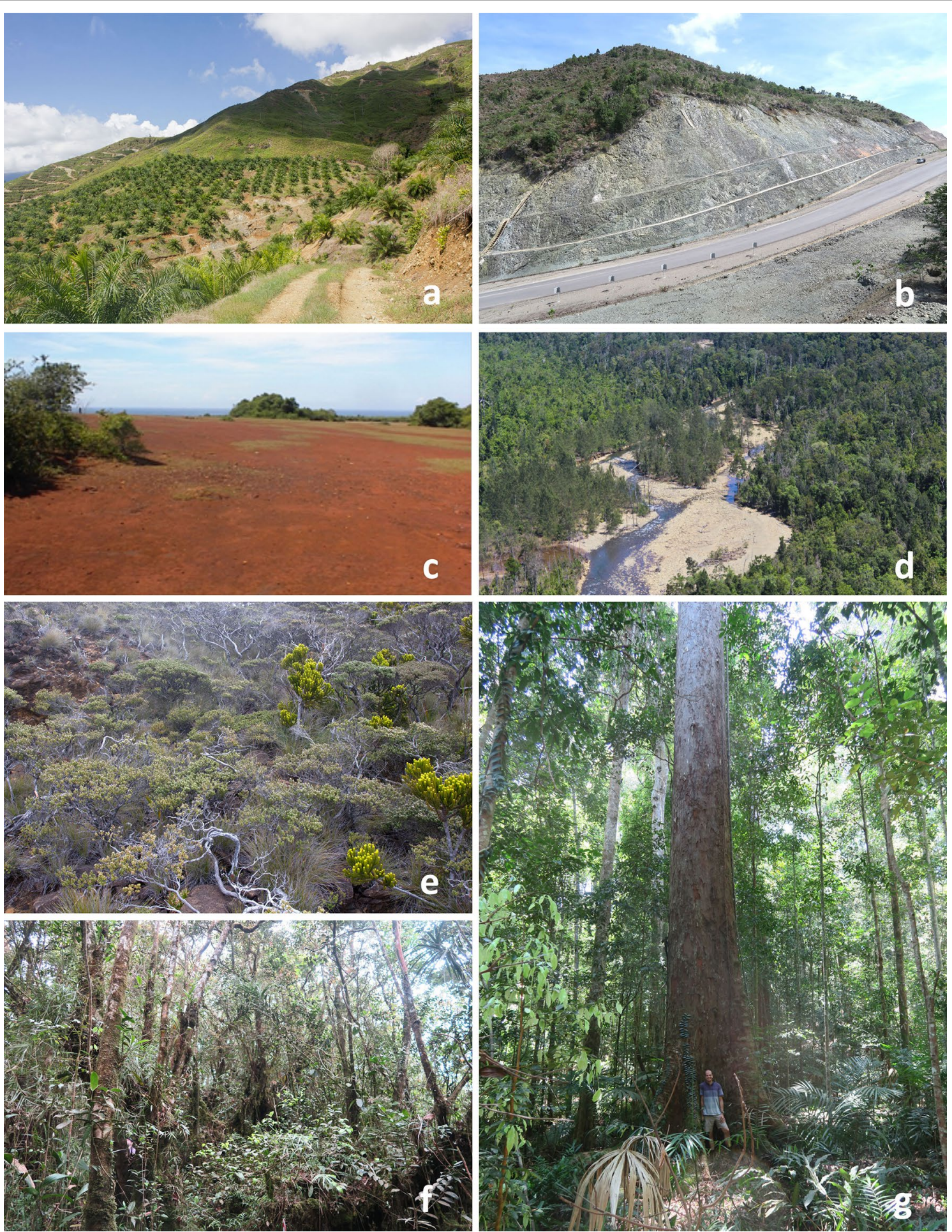

Fig. 2 Ultramafic outcrops and vegetation in South and Southeast Asia: a Oil palm estate in Sabah, Malaysia on eroding ultramafic soils. b Road cut through strongly serpentinised bedrock in Sabah, Malaysia. c Bare red Ferralsols at Ussangoda in Sri Lanka. d River flowing through an ultramafic outcrop in Halmahera, Indonesia. e Extremely stunted sub-alpine vegetation on ultramafic soils in Kinabalu park, Malaysia. f Montane cloud forest on ultramafic soils on Mount Silam, Malaysia. g Exceptionally tall lowland mixed dipterocarp forest on ultramafic soils in Sabah, Malaysia (all images are by A. van der Ent, except $\mathbf{c}$ by Y.A.S. Samithri and $\mathbf{g}$ by Isabella Zelano) 


\section{Plant endemism}

Ultramafic soils, often with disproportionately high numbers of endemic species (Anacker 2011), are prime settings to explore the nature of edaphic endemism (Rajakaruna 2004). In New Caledonia, 2150 species occur on ultramafic soils of which $83 \%$ are restricted to these soils (Jaffré 1992; Jaffré and L'Huillier 2010), whereas in Cuba, 920 species (approximately one-third of the taxa endemic to Cuba) are found exclusively on ultramafic soils (Borhidi 1992). Similar restrictions and notable floristic associations are also found on ultramafic outcrops of Mediterranean climates (including California; Alexander et al. 2007; Safford et al. 2005), as well as in South Africa/Zimbabwe and Australia (Anacker 2011; Brooks 1987).

The restriction of habitat specialists to ultramafic soils is generally considered a consequence of their inherent slow growth rates that leads them to being outcompeted on more favorable soils (Anacker 2014; Anacker et al. 2011; Kay et al. 2011). Although some growth experiments have shown that habitat specialists can grow faster on more nutrient-rich soils (Kruckeberg 1954), species from the ultramafic maquis in New Caledonia have inherently slow growth, albeit becoming larger under more fertile conditions (Jaffré 1980). Table 3 lists the countries within the South and Southeast Asian region with ultramafic floras, including the number of ultramafic-associated species documented and the number of ultramafic endemics described in each country.

In Sabah, Malaysia, Borneodendron aenigmaticum (Euphorbiaceae) is one of the few large rainforest trees restricted to ultramafic soils (Proctor et al. 1988a). Van der Ent and Wood $(2012,2013)$ describing orchid species associated with ultramafics in Sabah, Malaysia, documented many endemic species (Orchidaceae) restricted to narrow valleys with steep slopes, dominated by Gymnostoma sumatranum (Casuarinaceae) and Ceuthostoma terminale (Casuarinaceae). Further, van der Ent et al. (2015b) show habitat partitioning among ultramafic endemic Nepenthes species (Nepenthaceae) of Mount Kinabalu and Mount Tambuyukon, with distinct habitats and elevation ranges for the different Nepenthes taxa. Eriobotrya balgooyi (Rosaceae) was described as a new species restricted to ultramafic soils on a hill near the eastern ridge of Mount Kinabalu and on the nearby Mount Tambuyukon in Sabah, Malaysia (Wong and van der Ent 2014). The importance of scientific exploration of the ultramafics of Southeast Asia cannot be stressed enough; a survey on the ultramafic Mount Guiting-Guiting, Philippines (Argent et al. 2007) also led to the discovery of a new species, Lobelia proctorii (Campanulaceae).

Sri Lanka's ultramafic outcrops and their flora, compared with ultramafic floras of Southeast Asia and Australia-Pacific region (van der Ent et al. 2015c, d), have received relatively little attention partly because they do not harbor any endemic species nor many metal hyperaccumulators (Chathuranga et al. 2015). All species so far documented from the ultramafic outcrops of Sri Lanka also have non-ultramafic populations, and it is unclear whether the ultramafic populations are physiologically distinct (i.e. ecotypes).

\section{Cross-kingdom interactions}

Edaphically stressful substrates, like ultramafic soils, present plants with challenges that differ from more 'benign' substrates. Growing under such stress, ultramafic plants will likely encounter other organisms (herbivores, pathogens, beneficial insects and pathogens) that are also able to tolerate some of the same stressors affecting the plants (Strauss and Boyd 2011). There is evidence to suggest that pressures from enemies will be greater on edaphically stressful substrates than on normal soils (Strauss and Cacho 2013). Additionally, the enriched concentrations of certain trace elements, such as nickel, found in ultramafic soils may provide plants with opportunities for elemental defence (Boyd 2014). A significant body of research exists on plant-other biota interactions on ultramafic soils from temperate and Mediterranean climes, including studies on elemental defence (Boyd 2009), defence against pathogens (Hörger et al. 2013; Springer 2009), herbivory (Lau et al. 2008), mycorrhizal associations (Southworth et al. 2014), plant-pollinator interactions (Meindl et al. 2013; Wolf and Thorp 2011), and seed dispersal (Spasojevic et al. 2014). However, such studies are minimal in tropical Asia.

\section{Herbivory}

In the only known published study on herbivory in ultramafic ecosystems in the region, Proctor et al. (2000a) found that the percentage of leaf area consumed was similar for plants found on and off of ultramafic soils on Mount Bloomfield, Palawan (Philippines), although the actual leaf area consumed was greater for the ultramafic forest as it had plants with larger leaves. There was no relationship between herbivory and leaf elemental chemistry; even the metal-accumulating taxa were attacked by herbivores. Proctor et al. (2000a) speculate that the gall-forming and leaf-mining insects must be tolerant of nickel as they spend their entire juvenile stage in the leaf tissue.

Recent work by van der Ent and Mulligan (2015) show $\mathrm{Ni}$ accumulation in various parts of Ni hyperaccumulator plants occurring in Sabah, Malaysia, with the highest $\mathrm{Ni}$ concentration recorded in the phloem tissue (up to $7.9 \%$ in $R$. bengalensis) and phloem sap (up to $16.9 \%$ in Phyllanthus balgooyi); Ni localization in phloem tissue is visible by the bright green coloration in field-collected samples (Fig. 3b, f). The discovery of toxic levels of $\mathrm{Ni}$ in 

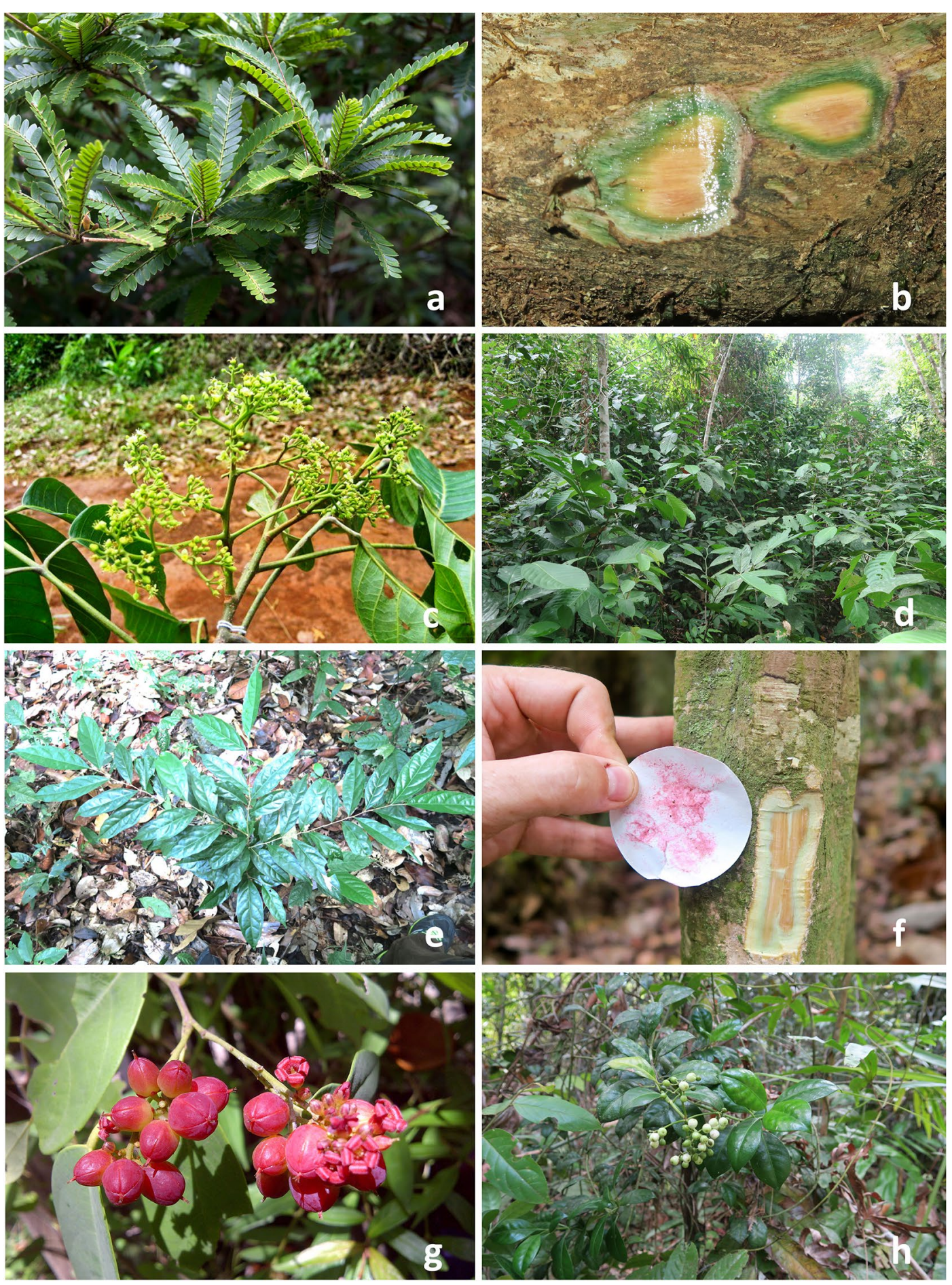

Fig. 3 Nickel hyperaccumulator plants in South and Southeast Asia: a Phyllanthus balgooyi (Phyllanthaceae) in Sabah, Malaysia is a small understorey tree. b Phloem sap exuding from Phyllanthus balgooyi contains up to 20 wt\% Ni. c Knema matanensis (Myristicaceae) in Sulawesi, Indonesia; d Rinorea bengalensis (Violaceae) can be locally dominant in lowland forest, in Sabah, Malaysia. e Dichapetalum gelonioides subsp. tuberculatum (Dichapetalaceae) from Mount Silam, Malaysia. f Main stem of Dichapetalum gelonioides subsp. tuberculatum showing its Ni-rich phloem tissue with colorimetric response in dimethylglyoxime test-paper. $\mathbf{g}$ Sarcotheca celebica (Oxalidaceae) from Sulawesi, Indonesia. $\mathbf{h}$ Psychotria sarmentosa (Rubiaceae) is the only known Ni hyperaccumulator in South and Southeast Asia that is a climber (all images are by A. van der Ent, except $\mathbf{c}, \mathbf{g}$ are by A. Tjoa, Tadulako University, Indonesia) 
the phloem tissue suggests that the increased $\mathrm{Ni}$ in the phloem provides a defence against phloem-sap feeding insects, pathogens, and other herbivores (Boyd 2014; Hanson et al. 2004). However, Geometric moth larvae (Erebidae: Erebinae:Poaphilini) were found feeding on the leaves of the Ni hyperaccumulator $P$. balgooyi, furthermore aphids were found feeding on Phyllanthus cf. securinegioides (van der Ent et al. 2015f).

\section{Mycorrhizal associations}

Pisolithus tinctorius (Sclerodermataceae), an ectomycorrhizal fungus, is found in the rhizosphere of Eucalyptus urophylla (Myrtaceae) from ultramafic soils in the Philippines, New Caledonia, and Western Australia (Aggangan et al. 1998). Pisolithus tinctorius was cultured with E. urophylla to determine the effects of $\mathrm{Cr}$ and $\mathrm{Ni}$ on the fungal growth rate. The fungus concentrates metals in the extramatrical hyphae and extra-hyphal slime and is particularly tolerant of high concentrations of $\mathrm{Ni}$ and Cr. There was geographic variation in terms of metal tolerance in the fungus, with the New Caledonian isolate outperforming both the Australian and the Philippines isolates. The Philippines isolate grew well on agar in the presence of $\mathrm{Cr}$ up to $2000 \mu \mathrm{mol} \mathrm{L} \mathrm{L}^{-1}$ and $\mathrm{Ni}$ up to $200 \mu \mathrm{mol} \mathrm{L}{ }^{-1}$, but formed fewer mycorrhizae in vitro and in vivo than its counterparts from New Caledonia and Western Australia.

\section{Soil invertebrates}

A study comparing termite assemblages on ultramaficderived forest soils to those on non-ultramafic soils in Borneo, Malaysia shows that ultramafic sites have low species density $(<35 \%)$, low relative abundance $(<30 \%)$, a virtual absence of soil-feeders, significantly fewer wood-feeders, and a near-absence of species of Rhinotermitidae, Amitermes-group, Termes-group, Pericapritermes-group and Oriensubulitermes-group (Jones et al. 2010). The authors suggest that metal toxicity, high $\mathrm{pH}$ disrupting gut physiology, metal poisoning of essential microbiota in the termite gut, and metal bioaccumulation by gut microbes with subsequent poisoning of the termite host, as possible reasons for the depauperate termite communities on ultramafic soils.

A study on the patterns of Oribatid mite communities in relation to elevation and geology on the slopes of Mount Kinabalu, Sabah, Malaysia, shows that the density and morphospecies richness of Oribatid mites are greater in non-ultramafic soils than in the ultramafic soils at each of the same elevations (Hasegawa et al. 2006). The density and richness of Oribatid mites decreased with elevation on both substrates, but the effects of elevation on their density in non-ultramafic soil were less significant than in the ultramafic substrate.
An investigation of the invertebrate communities in forest litter and soil on Mount Guiting-Guiting in the Philippines, shows that ultramafic soils, even at higher elevations, were not poor in soil invertebrates, including Oligochaeta (Thomas and Proctor 1997), similar to earlier findings on Mount Silam, Sabah (Leakey and Proctor 1987).

\section{Physiology and genetics}

There is considerable interest in understanding the physiology and the underlying genetic basis for traits conferring adaptation to ultramafic soils (Bratteler et al. 2006; Palm and Van Volkenburgh 2014; von Wettberg and Wright 2011; Wu et al. 2008). The advent of novel molecular methods has provided unique approaches to exploring stress tolerance (Selby et al. 2014; Visioli and Marmiroli 2013) and ultramafic-associated plants will continue to provide model systems for such investigations (Arnold et al. 2016; von Wettberg et al. 2014). While these advances have not yet been made in tropical Asia, the region provides numerous opportunities for investigating the physiological and genetic aspects of adaptation to ultramafic soils. To date, much of the research in South and Southeast Asia has focused on discovering new hyperaccumulating plant species from ultramafic soils in the region.

\section{Trace element hyperaccumulation}

Plants found on ultramafic soils have long-been recognized as model systems to explore trace element hyperaccumulation (Gall and Rajakaruna 2013). There are well over $450 \mathrm{Ni}$ hyperaccumulator plant species globally, all occurring on ultramafic soils (van der Ent et al. 2013c). Ultramafic associated plants are known to hyperaccumulate cobalt (Co) and $\mathrm{Cu}\left(>300 \mu \mathrm{g} \mathrm{g}^{-1}\right.$ in their dry leaf tissue), and $\mathrm{Ni}\left(>1000 \mu \mathrm{g} \mathrm{g}^{-1}\right.$ in their dry leaf tissue). For recent reviews of trace element hyperaccumulation, see Reeves (2003), Krämer (2010), van der Ent et al. (2013c, 2015e) and Pollard et al. (2014). Table 4 lists documented hyperaccumulator plants from the South and Southeast Asia region, listing the element hyperaccumulated, country of discovery, and relevant references. Figure 3 documents some of the nickel hyperaccumulator plants discovered from ultramafic soils in parts of South and Southeast Asia.

In one of the earliest geoecological studies of the region, Wither and Brooks (1977) and Brooks et al. (1977b) analysed herbarium samples of plants originating from Obi Island (North Moluccas). They identified Myristica laurifolia var. bifurcata (Myristicaceae), Planchonella oxyhedra (Sapotaceae), and Trichospermum kjellbergii (Malvaceae) as hyperaccumulators of $\mathrm{Ni}$. The authors then analysed Ni concentrations in herbarium specimens of $T$. kjellbergii and $P$. oxyhedra from 


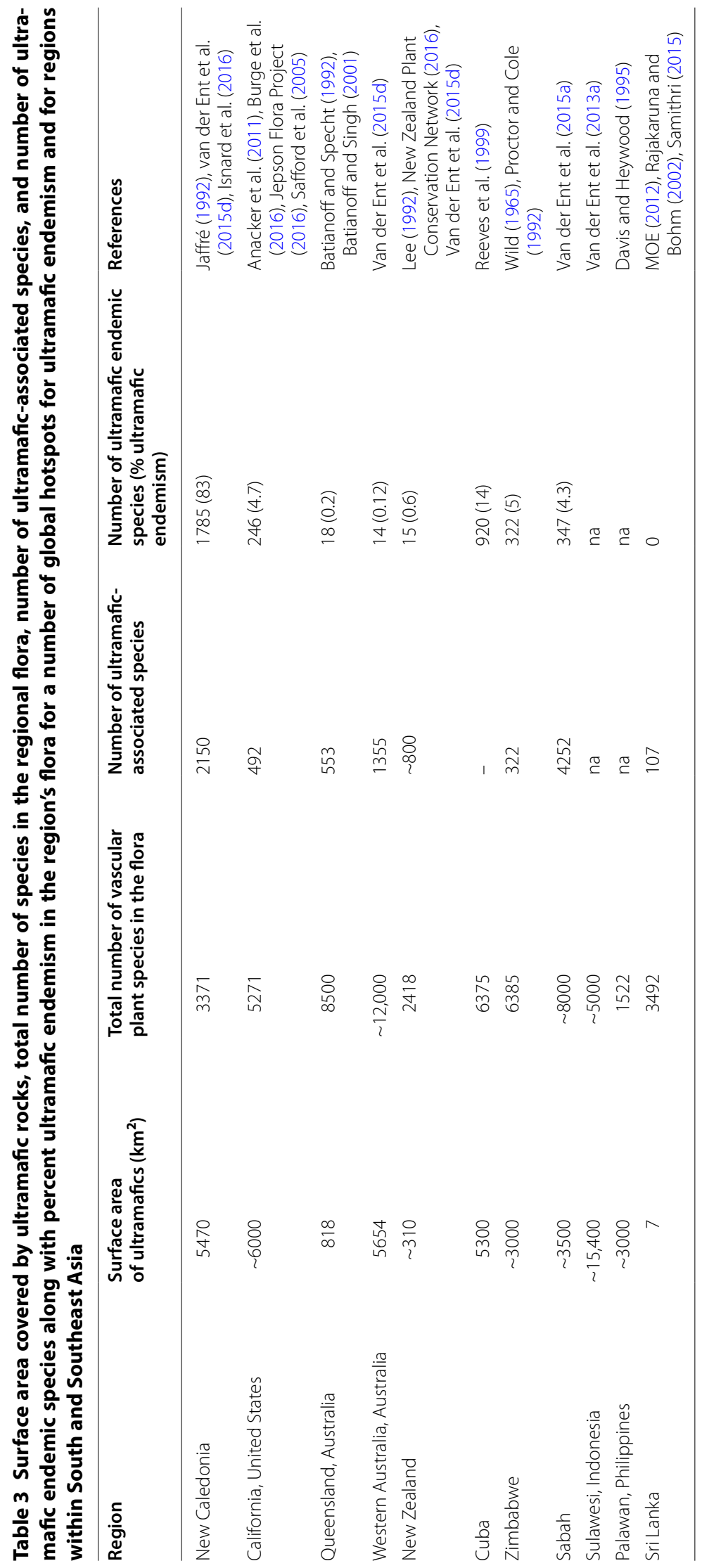



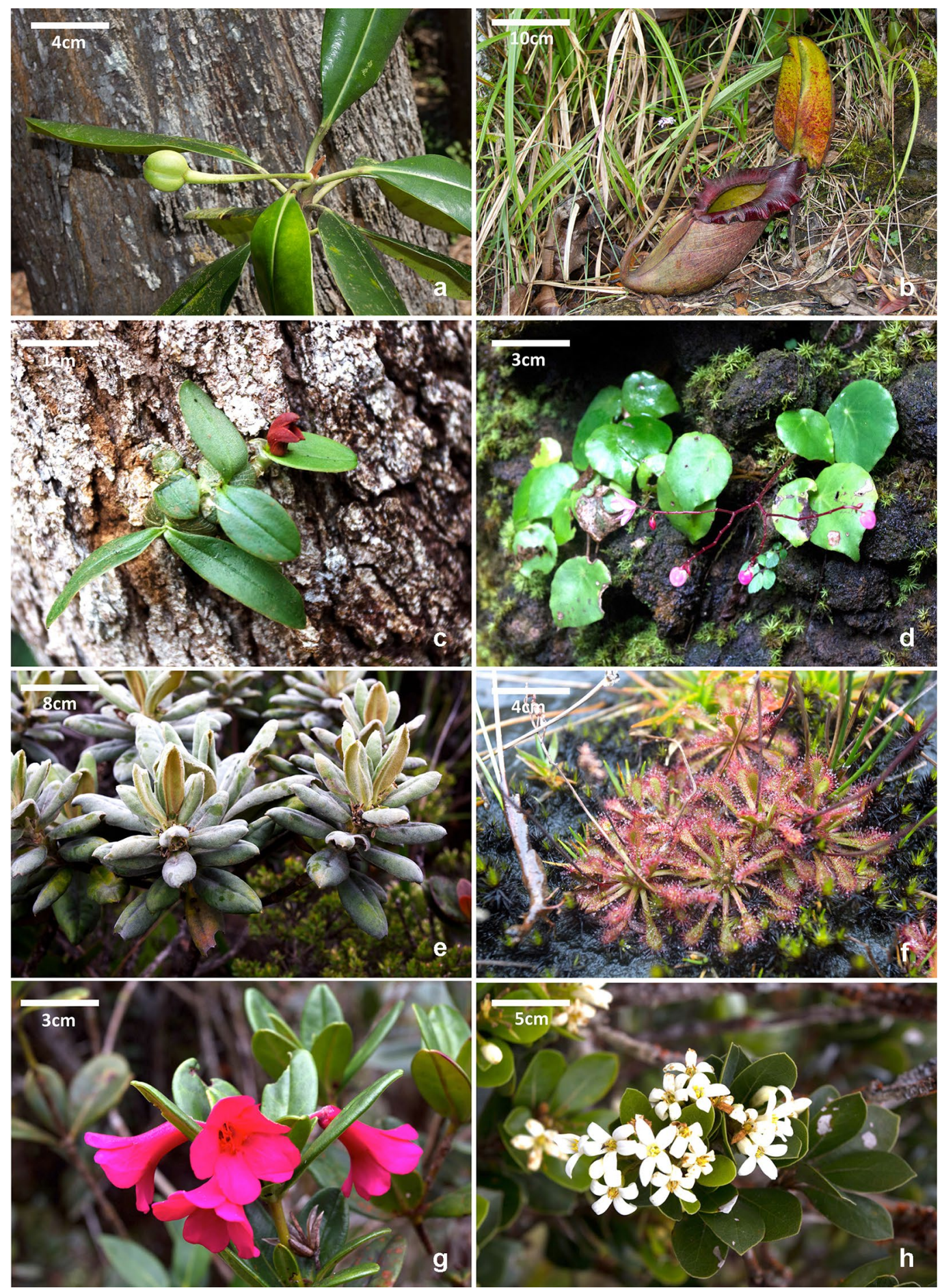

Fig. 4 Ultramafic edaphic endemics from South and Southeast Asia: a The monotypic tree Borneodendron aenigmaticum (Euphorbiaceae) is endemic to Sabah (Malaysia) on ultramafic soils in the lowlands. b The world's largest carnivorous pitcher plant, Nepenthes rajah (Nepenthaceae) is endemic to Kinabalu Park in Sabah where it occurs in the montane zone. c The epiphytic or lithophytic orchid Porpax borneensis (Orchidaceae) is restricted to ultramafic outcrops in Sabah, Malaysia. d The recently described Begonia moneta (Begoniaceae) occurs lithophytically in lowland ultramafic forest in Sabah, Malaysia. e Scaevola verticillata (Goodeniaceae) is endemic to the summit of the ultramafic Mount Tambukon in Sabah, Malaysia. f The carnivorous Drosera ultramafica (Droseraceae) is endemic to a limited number of mountainous ultramafic outcrops in Malaysia and the Philippines. $\mathbf{g}$ Rhododendron baconii (Ericaceae) is another hyper-endemic restricted to Kinabalu Park, Sabah, Malaysia. $\mathbf{h}$ The specific epithet of Pittosporum peridoticola (Pittosporaceae) indicates its habitat is on ultramafic soils in Sabah, Malaysia (all images are by A. van der Ent) 
throughout their range in Southeast Asia and Oceania. The findings confirmed previously known ultramafic areas in Sulawesi and Indonesian New Guinea, as well as one in Ambon (South Moluccas) which was not documented on geological maps. Their suspicions about the substrate were confirmed by a 1994 geological study that mapped peridotite and serpentinite outcrops in both Ambon and Seram (Linthout and Helmers 1994). A more recent study in Soroako, Sulawesi, examined leaf tissue from 23 plant species from former $\mathrm{Ni}$ mining sites in search of hyperaccumulator plants (Netty et al. 2012). As a result, Sarcotheca celebica (Oxalidaceae) was confirmed as a Ni hyperaccumulator, with $1039 \mu \mathrm{g} \mathrm{g}^{-1} \mathrm{Ni}$ in dry leaf tissue.

In a study describing the general influence of the ultramafic geochemistry on growth patterns of plants overlying two Malaysian massifs, the Bukit Rokan and Petasih along the Bentong-Raub suture zone on the Peninsula, Tashakor et al. (2013) document that the serpentinite of the area is strongly weathered and gives rise to characteristic red lateritic soils (Ferralsols). They point out that the greatest physiological stress experienced by plants growing on ultramafic soils is due to the low $\mathrm{Ca}$ : $\mathrm{Mg}$ ratio and the generally low available nutrients, and not due to potentially phytotoxic elements present in the soil, which are, for the most part, not in a plant-available form.

In a study of the Bela Ophiolite in the Wadh area of Balochistan, Pakistan, Naseem et al. (2009) discovered Pteropyrum olivieri (Polygonaceae) in a localized population over ultramafic soils. Although the plant did not hyperaccumulate, it had moderate concentrations of $\mathrm{Ni}$, $\mathrm{Co}$, and $\mathrm{Cr}$ in its tissues, typical of most plants growing on ultramafic soils.

The ultramafics of Malaysia and Indonesia have received considerable attention with regard to taxa with high metal-accumulating behavior. A chemical analysis of leaf litter from trees growing on ultramafics in Sabah, Malaysia (Proctor et al. 1989) confirmed that trees grow at low foliar nutrient concentrations and can concentrate $\mathrm{Ca}$ in their leaf tissue. Leaf litter showed an average $\mathrm{Ca}: \mathrm{Mg}$ ratio as well as a high level of $\mathrm{Ni}$, suggesting that senescence may act as a way of excreting excess $\mathrm{Ni}$. From analysis of leaf litter, they found that Shorea tenuiramulosa (Dipterocarpaceae) and an unidentified species of Syzygium (Myrtaceae) accumulated $\mathrm{Ni}$ and $\mathrm{Mn}$, respectively, with $1000 \mu \mathrm{g} \mathrm{g}^{-1} \mathrm{Ni}$ and 13,700 $\mu \mathrm{g} \mathrm{g}^{-1} \mathrm{Mn}$ dry leaf weight. Proctor et al. (1994) also reported a yet to be named Ni-hyperaccumulating species of Rinorea from Mt Piapi on Karakelong Island, northeast of Sulawesi in Indonesia with up to $1830 \mu \mathrm{g} \mathrm{g}^{-1}$ foliar Ni.

In an analysis of 51 herbarium specimens from both Malaysia and Indonesia, including from Mount Kinabalu (Sabah), Soroako and Malili (Sulawesi) and Yapen
Island, Reeves (2003) found high Ni values in Phyllanthus insulae-japen (Phyllanthaceae), which had been collected once in 1961, and in R. bengalensis, Brackenridgea palustris subsp. kjellbergii (Ochnaceae), Glochidion spp. (Phyllanthaceae), and two species of Psychotria (Rubiaceae) which could not be identified to species level. One ultramafic subspecies of $D$. gelonioides was identified as a $\mathrm{Ni}$ hyperaccumulator (subsp. tuberculatum), whereas another subspecies was confirmed as a $\mathrm{Zn}$ hyperaccumulator on non-ultramafic soils (subsp. pilosum) (Baker et al. 1992).

In recent studies of Mt. Kinabalu, van der Ent et al. (2013b, 2015a, f) discovered nine species of Ni hyperaccumulators from the flora of Kinabalu Park in Sabah, Malaysia. Previously known hyperaccumulators from the region included R. bengalensis (Brooks and Wither 1977a, b), Rinorea javanica (Brooks et al. 1977a), P. balgooyi (Phyllanthaceae; Hoffmann et al. 2003), D. gelonioides (Baker et al. 1992), Psychotria cf. gracilis (Rubiaceae; Reeves 2003), and Shorea tenuiramulosa (Proctor et al. 1989). Van der Ent et al. (2013b, 2015f) added several more Ni hyperaccumulators, including Actephila alanbakeri (Cleistanthus sp. nov. in the original report)

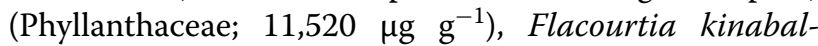
uensis (Salicaceae; $7280 \mu \mathrm{g} \mathrm{g}^{-1}$ ), Glochidion mindorense (Phyllanthaceae; $2280 \mu \mathrm{g} \mathrm{g}^{-1}$ ), Kibara coriacea (Monimiaceae; $5840 \mu \mathrm{g} \mathrm{g}^{-1}$ ), Mischocarpus sundaicus (Sapindaceae) $\left(4425 \mathrm{\mu g} \mathrm{g}^{-1}\right)$, Phyllanthus cf. securinegioides (Phyllanthaceae; 23,300 $\mu \mathrm{g} \mathrm{g}^{-1}$ ), Psychotria sarmentosa (Rubiaceae; 24,200 $\mathrm{gg} \mathrm{g}^{-1}$ ), Walsura pinnata (Meliaceae; $4580 \mathrm{\mu g} \mathrm{g}^{-1}$ ), and Xylosma luzoniensis (Salicaceae; $5360 \mu \mathrm{g} \mathrm{g}^{-1}$ ) to the list, thereby documenting the highest number of Ni hyperaccumulators (15) known from any region within South and Southeast Asia.

In an effort to understand the factors contributing to $\mathrm{Ni}$ hyperaccumulation in Sabah, Malaysia, van der Ent et al. (2016b) examined the soil chemistry associated with 18 Ni hyperaccumulator plant species, comparing the chemistry of ultramafic soils where $\mathrm{Ni}$ hyperaccumulators were absent. The results showed that Ni hyperaccumulators are restricted to circum-neutral soils with relatively high phytoavailable $\mathrm{Ca}, \mathrm{Mg}$, and $\mathrm{Ni}$. They hypothesized that either hyperaccumulators excrete large amounts of root exudates, thereby increasing $\mathrm{Ni}$ phytoavailability through intense rhizosphere mineral weathering, or that they have extremely high $\mathrm{Ni}$ uptake efficiency, thereby severely depleting $\mathrm{Ni}$ and stimulating re-supply of $\mathrm{Ni}$ via diffusion from labile Ni pools. Their results, however, tend to favor the latter hypothesis.

Nuclear microprobe imaging (micro-PIXE) shows that in $P$. balgooyi collected from ultramafic soils in Sabah, Malaysia, Ni concentrations were very high in the phloem of the stems and petioles, while in the leaves $\mathrm{Ni}$ 
was enriched in the major vascular bundles (MesjaszPrzybylowicz et al. 2015). The preferential accumulation of $\mathrm{Ni}$ in the vascular tracts suggests that $\mathrm{Ni}$ is present in a metabolically active form. This research is important as the elemental distribution of $P$. balgooyi differs from that of many other Ni hyperaccumulators from temperate and Mediterranean regions where $\mathrm{Ni}$ is preferentially accumulated in leaf epidermal cells (Bhatia et al. 2004; Broadhurst et al. 2004; Tylko et al. 2007; Baklanov 2011).

In the Philippines, much of the ultramafic vegetation remains underexplored (Fernando et al. 2008; but see Baker et al. 1992; Fernando et al. 2013; Proctor et al. 1998, 2000a, b). Studies to date have revealed new Ni hyperaccumulators (e.g. Fernando and Rodda 2013; Hoffmann et al. 2003), including Breynia cernua (Phyllanthaceae; Gotera et al. 2014) and P. balgooyi, P. erythrotrichus, and P. securinegioides (Phyllanthaceae; Hoffmann et al. 2003; Quimado et al. 2015). A recent study described Rinorea niccolifera (Violaceae) as a novel taxon and Ni hyperaccumulator from Luzon Island, Philippines (Fernando et al. 2014).

Although in Sri Lanka's ultramafic outcrops are not associated with many $\mathrm{Ni}$ hyperaccumulator species, unlike those in Sabah, Malaysia (van der Ent et al. 2015a), several plant species currently found at Ussangoda hyperaccumulate $\mathrm{Ni}$ (see citations in Chathuranga et al. 2015; Samithri 2015). Notable in this regard are Evolvulus alsinoides (Convolvulaceae), Hybanthus enneaspermus (Violaceae), Flacourtia indica (Flacourtiaceae), Olax imbricata (Olacaceae), Toddalia asiatica (Rutaceae), Euphorbia heterophylla (Euphorbiaceae), Vernonia cinerea (Asteraceae) and Crotalaria sp. (Fabaceae). Senevirathne et al. (2000) also document Striga euphrasioides (Orobanchaceae), Cassia mimosoides (Fabaceae), and Blumea obliqua (Asteraceae) from Ussangoda as hyperaccumulating $\mathrm{Ni}$, although subsequent studies have failed to confirm this earlier report. Five $\mathrm{Cu}$ hyperaccumulators [Geniosporum tenuiflorum (Lamiaceae; now Ocimum tenuiflorum), Clerodendrum infortunatum (Lamiaceae), Croton bonplandianus (Euphorbiaceae), Waltheria indica (Malvaceae), and Tephrosia villosa (Fabaceae)] are also found on ultramafic outcrops in Sri Lanka (Rajakaruna and Bohm 2002). Based on revised criteria for $\mathrm{Cu}$ hyperaccumulation (van der Ent et al. 2013c), Calotropis gigantea, Carissa spinarum, Cassia auriculata, Abutilon indicum, and Phyllanthus sp. undet., analysed by Rajakaruna and Bohm (2002), now also qualify as hyperaccumulators of $\mathrm{Cu}$ (Table 4). Although $\mathrm{Cu}$ hyperaccumulation is not a common phenomenon among ultramafic plants, a recent study has also documented unusual $\mathrm{Cu}$ uptake in a number of ultramafic plants in Malaysia and Brazil (van der Ent and Reeves 2015).

\section{Evolutionary aspects}

Ultramafic outcrops often harbor populations which are morphologically and physiologically distinct from those found on non-ultramafic soils. Such intraspecific variation, especially with respect to functionally important traits, is common in many ultramafic taxa worldwide (O'Dell and Rajakaruna 2011). Such variation can result from both local adaptation (i.e., ecotypic differentiation; Sambatti and Rice 2006; Turner et al. 2010) or phenotypic plasticity (Murren et al. 2006; Wu et al. 2010), and must be examined on a case-by-case basis. Suitable methods of examination include reciprocal or unilateral transplant experiments and common garden studies (Wright and Stanton 2011), as well as functional genomic and proteomic approaches (Selby et al. 2014; von Wettberg et al. 2014; von Wettberg and Wright 2011). Detecting intraspecific variation is the first step toward any investigation on the causes and consequences of adaptive evolution. Populations exhibiting intraspecific variation on ultramafic and non-ultramafic soils have led to numerous studies of speciation (Anacker 2014; Kay et al. 2011) and phylogenetic investigations (Anacker 2011; Anacker et al. 2011; Anacker and Harrison 2012), advancing our understanding of evolutionary and ecological theory (Harrison and Rajakaruna 2011). Molecular phylogenetic methods provide a unique protocol for testing and establishing species relationships, helping to shed light on how ultramafic endemics evolve (Baldwin 2005). The analysis of phylogenies for 23 genera from California shows that ultramafic endemics exhibit few transitions out of the endemic state (Anacker et al. 2011), suggesting that adaptation to ultramafics and subsequent diversification can lead to an evolutionary "dead end". But ultramafic lineages may not always represent evolutionary "dead ends" and may have the potential to further diversify via independent polyploidization and hybridization, even providing a pathway to radiate off ultramafic soils (Kolár et al. 2012).

Compared to these studies from other regions of the world, there is little information on evolutionary aspects of plants associated with ultramafic soils in South and Southeast Asia. A recent study from Sri Lanka shows that the ultramafic and non-ultramafic populations of Fimbristylis ovata (Cyperaceae) may be locally adapted to their respective soils (Chathuranga et al. 2015). The ultramafic population translocated significantly more $\mathrm{Ni}$ from its roots to shoots (translocation factor 0.43) than the non-ultramafic population (translocation factor 0.29). However, additional studies are required to determine whether the populations of $F$. ovata, or other species, including those hyperaccumulating metals such as $\mathrm{Ni}$ and $\mathrm{Cu}$, deserve ecotypic recognition. Several ultramafic-associated taxa in Sri Lanka might benefit from 
Table 4 Unusual foliar elemental accumulation (Ni, $\mathrm{Co}, \mathrm{Cu}, \mathrm{Mn}$ or $\mathrm{Zn}$-maximum recorded values in $\mu \mathrm{g} \mathrm{g}^{-1}$ ) in plants from South and Southeast Asia

\begin{tabular}{|c|c|c|c|c|c|c|c|c|c|}
\hline Family & Species & Life-form & Locality & $\mathrm{Ni}$ & $\mathrm{Cu}$ & Co & $M n$ & $\mathrm{Zn}$ & Reference \\
\hline Acanthaceae & $\begin{array}{c}\text { Daedalacanthus } \\
\text { suffruticosus }\end{array}$ & Shrub & India & $1235-1862$ & - & - & - & - & Datta et al. (2015) \\
\hline Acanthaceae & $\begin{array}{l}\text { Ptyssiglottis cf. } \\
\text { fusca }\end{array}$ & Herb & Sabah, Malaysia & 1160 & - & - & - & & $\begin{array}{l}\text { Van der Ent et al. } \\
\qquad(2015 f)\end{array}$ \\
\hline Amaranthaceae & Aervascandens & Herb & $\begin{array}{l}\text { Sulawesi, Indo- } \\
\text { nesia }\end{array}$ & - & 395 & - & - & - & Brooks et al. (1978) \\
\hline Amaranthaceae & Cyathula prostrata & Herb & $\begin{array}{l}\text { Sulawesi, Indo- } \\
\text { nesia }\end{array}$ & - & 553 & - & - & - & Brooks et al. (1978) \\
\hline Apocynaceae & Calotropis gigantea & Climber & Sri Lanka & - & 583 & - & - & - & $\begin{array}{l}\text { Rajakaruna and } \\
\text { Bohm (2002) }\end{array}$ \\
\hline Apocynaceae & Carissa spinarum & Climber & Sri Lanka & - & 702 & - & - & - & $\begin{array}{l}\text { Rajakaruna and } \\
\text { Bohm (2002) }\end{array}$ \\
\hline Asteraceae & Vernonia actaea & Herb & $\begin{array}{l}\text { Sulawesi, Indo- } \\
\text { nesia }\end{array}$ & - & 300 & - & - & - & Brooks et al. (1978) \\
\hline Asteraceae & Vernonia cinerea & Herb & Sri Lanka & 1026 & - & - & - & - & Samithri (2015) \\
\hline Chrysobalanaceae & Licania splendens & Shrub & $\begin{array}{l}\text { Zambales, Philip- } \\
\text { pines }\end{array}$ & 2728 & - & - & - & - & $\begin{array}{l}\text { Fernando et al. } \\
\text { (2013) }\end{array}$ \\
\hline Convolvulaceae & Evolvulus alsinoides & Herb & Sri Lanka & 1478 & - & & - & - & $\begin{array}{l}\text { Rajakaruna and } \\
\text { Bohm (2002) }\end{array}$ \\
\hline Dichapetalaceae & $\begin{array}{l}\text { Dichapetalum } \\
\text { gelonioides } \\
\text { subsp. pilosum }\end{array}$ & Climber/shrub & Sabah, Malaysia & - & - & - & - & 7000 & Baker et al. (1992) \\
\hline Dichapetalaceae & $\begin{array}{l}\text { Dichapetalum } \\
\text { gelonioides } \\
\text { subsp. sumatra- } \\
\text { num }\end{array}$ & Shrub & SE Asia & - & - & - & - & 30,000 & Baker et al. (1992) \\
\hline Dichapetalaceae & $\begin{array}{l}\text { Dichapetalum } \\
\text { geloniodes } \\
\text { subsp. tubercu- } \\
\text { latum }\end{array}$ & Shrub & $\begin{array}{r}\text { Malaysia and } \\
\text { Philippines }\end{array}$ & 26,600 & - & - & - & - & Baker et al. (1992) \\
\hline Dichapetalaceae & $\begin{array}{l}\text { Dichapetalum } \\
\text { gelonioides } \\
\text { subsp. anda- } \\
\text { manicum }\end{array}$ & Shrub & $\begin{array}{l}\text { Andaman Islands, } \\
\text { India }\end{array}$ & $3160 ; 9740-36,100$ & - & - & - & - & $\begin{array}{l}\text { Brooks (1987), Datta } \\
\text { et al. (2015) }\end{array}$ \\
\hline Dipterocarpaceae & $\begin{array}{l}\text { Shorea tenuiramu- } \\
\text { losa }\end{array}$ & Tree & Sabah, Malaysia & 1790 & - & - & - & - & $\begin{array}{l}\text { Proctor et al. (1988a, } \\
\text { b), Van der Ent } \\
\text { et al. (2015a, b, c, } \\
\text { d, e, f, g) }\end{array}$ \\
\hline Euphorbiaceae & $\begin{array}{l}\text { Croton bonplan- } \\
\text { dianus }\end{array}$ & Tree & Sri Lanka & - & 2163 & - & - & - & $\begin{array}{l}\text { Rajakaruna and } \\
\text { Bohm (2002) }\end{array}$ \\
\hline Euphorbiaceae & $\begin{array}{l}\text { Euphorbia thymi- } \\
\text { folia }\end{array}$ & Shrub & Sri Lanka & 1074 & - & - & - & - & Samithri (2015) \\
\hline Fabaceae & Cassia auriculata & Shrub & Sri Lanka & - & 885 & - & - & - & $\begin{array}{l}\text { Rajakaruna and } \\
\text { Bohm (2002) }\end{array}$ \\
\hline Fabaceae & Dalbergia beccarii & Shrub & Sabah, Malaysia & 2623 & - & - & - & - & $\begin{array}{l}\text { Van der Ent and } \\
\text { Reeves (2015) }\end{array}$ \\
\hline Fabaceae & Tephrosia villosa & Herb & Sri Lanka & - & 1858 & - & - & - & $\begin{array}{l}\text { Rajakaruna and } \\
\text { Bohm (2002) }\end{array}$ \\
\hline Lamiaceae & $\begin{array}{l}\text { Clerodendrum } \\
\text { infortunatum }\end{array}$ & Herb & Sri Lanka & - & 2278 & - & - & - & $\begin{array}{l}\text { Rajakaruna and } \\
\text { Bohm (2002) }\end{array}$ \\
\hline Lamiaceae & $\begin{array}{l}\text { Coleus scutellari- } \\
\text { oides }\end{array}$ & Herb & Sri Lanka & - & 500 & - & - & - & Brooks et al. (1978) \\
\hline Lamiaceae & $\begin{array}{l}\text { Ocimum tenuiflo- } \\
\text { rum }\end{array}$ & Herb & Sri Lanka & - & 2266 & - & - & - & $\begin{array}{l}\text { Rajakaruna and } \\
\text { Bohm (2002) }\end{array}$ \\
\hline Loganiaceae & $\begin{array}{l}\text { Strychnos anda- } \\
\text { manensis }\end{array}$ & Climber & India & $2606-6893$ & - & - & - & - & Datta et al. (2015) \\
\hline Loganiaceae & Strychnos minor & Climber & India & $3220-10,214$ & - & - & - & - & Datta et al. (2015) \\
\hline
\end{tabular}


Table 4 continued

\begin{tabular}{|c|c|c|c|c|c|c|c|c|c|}
\hline Family & Species & Life-form & Locality & $\mathrm{Ni}$ & $\mathrm{Cu}$ & Co & $M n$ & $\mathrm{Zn}$ & Reference \\
\hline Loganiaceae & $\begin{array}{l}\text { Strychnos wal- } \\
\text { lichiana }\end{array}$ & Climber & India & $2924-15,630$ & - & - & - & - & Datta et al. (2015) \\
\hline Malvaceae & Abutilon indicum & Shrub & Sri Lanka & - & 915 & - & - & - & $\begin{array}{l}\text { Rajakaruna and } \\
\text { Bohm (2002) }\end{array}$ \\
\hline Malvaceae & Waltheria indica & Shrub & Sri Lanka & - & 1504 & - & - & - & $\begin{array}{l}\text { Rajakaruna and } \\
\text { Bohm (2002) }\end{array}$ \\
\hline Meliaceae & $\begin{array}{l}\text { Walsura mono- } \\
\text { phylla }\end{array}$ & Tree & $\begin{array}{r}\text { Malaysia and } \\
\text { Philippines }\end{array}$ & 7090 & - & - & - & - & Baker et al. (1992) \\
\hline Meliaceae & Walsura pinnata & Tree & SE Asia & 4580 & - & - & - & - & $\begin{array}{l}\text { Van der Ent et al. } \\
\qquad(2015 f)\end{array}$ \\
\hline Monimiaceae & Kibara coriacea & Tree & SE Asia & 5840 & - & - & - & - & $\begin{array}{l}\text { Van der Ent et al. } \\
\quad(2015 f)\end{array}$ \\
\hline Moraceae & Ficus brevicuspis & Tree & India & $28,322-30,564$ & - & - & - & - & Datta et al. (2015) \\
\hline Myristicaceae & Knema matanensis & Tree & Indonesia & 5000 & - & - & - & - & $\begin{array}{l}\text { Van der Ent et al. } \\
\qquad(2013 a)\end{array}$ \\
\hline Myristicaceae & $\begin{array}{l}\text { Myristica laurifolia } \\
\text { var. bifurcata }\end{array}$ & Tree & Indonesia & 1100 & - & & - & - & $\begin{array}{l}\text { Wither and Brooks } \\
\text { (1977) }\end{array}$ \\
\hline Myrtaceae & $\begin{array}{l}\text { Decaspermum } \\
\text { blancoi }\end{array}$ & Shrub & $\begin{array}{l}\text { Zambales, Philip- } \\
\text { pines }\end{array}$ & 1996 & - & & - & - & $\begin{array}{l}\text { Fernando et al. } \\
\text { (2013) }\end{array}$ \\
\hline Ochnaceae & $\begin{array}{l}\text { Brackenridgea } \\
\text { palustris subsp. } \\
\text { foxworthyi }\end{array}$ & Shrub & Philippines & 7600 & - & - & - & - & Baker et al. (1992) \\
\hline Ochnaceae & $\begin{array}{l}\text { Brackenridgea } \\
\text { palustris subsp. } \\
\text { kjellbergii }\end{array}$ & Tree & $\begin{array}{l}\text { Sulawesi, Indo- } \\
\text { nesia }\end{array}$ & 1440 & - & - & - & - & Reeves (2003) \\
\hline Ochnaceae & Ochna integerrima & Tree & India & $2465-5210$ & - & - & - & - & Datta et al. (2015) \\
\hline Olacaceae & Olax imbricata & Tree & Sri Lanka & 1082 & - & - & - & - & Samithri (2015) \\
\hline Oxalidaceae & Sarcotheca celebica & Tree & Indonesia & 1000 & - & - & - & - & $\begin{array}{l}\text { Van der Ent et al. } \\
\qquad(2013 a, b, c)\end{array}$ \\
\hline Papilionaceae & Cassia sophera & Shrub & $\begin{array}{l}\text { Sulawesi, Indo- } \\
\text { nesia }\end{array}$ & - & 333 & - & - & - & Brooks et al. (1978) \\
\hline Phyllanthaceae & $\begin{array}{l}\text { Actephila alan- } \\
\text { bakeri }\end{array}$ & Shrub & Sabah, Malaysia & 11,520 & - & - & - & - & $\begin{array}{l}\text { Van der Ent et al. } \\
\quad(2016 c)\end{array}$ \\
\hline Phyllanthaceae & $\begin{array}{l}\text { Aporosa chalaro- } \\
\text { carpa }\end{array}$ & Tree & SE Asia & 1560 & - & - & - & - & $\begin{array}{l}\text { Van der Ent et al. } \\
\qquad(2015 f)\end{array}$ \\
\hline Phyllanthaceae & $\begin{array}{l}\text { Baccaurea lanceo- } \\
\text { lata }\end{array}$ & Tree & SE Asia & 1450 & - & - & - & - & $\begin{array}{l}\text { Van der Ent et al. } \\
\quad(2015 f)\end{array}$ \\
\hline Phyllanthaceae & Breynia cernua & Shrub & $\begin{array}{l}\text { Zambales, Philip- } \\
\text { pines }\end{array}$ & 3573 & - & - & - & - & Gotera et al. (2014) \\
\hline Phyllanthaceae & Cleistanthus sp. 1 & Tree & Sabah, Malaysia & 2110 & - & - & - & - & $\begin{array}{l}\text { Van der Ent et al. } \\
\qquad(2015 f)\end{array}$ \\
\hline Phyllanthaceae & $\begin{array}{l}\text { Glochidion aff. } \\
\text { acustylum }\end{array}$ & Tree & $\begin{array}{l}\text { Sulawesi, Indo- } \\
\text { nesia }\end{array}$ & 6060 & - & - & - & - & Reeves (2003) \\
\hline Phyllanthaceae & $\begin{array}{l}\text { Glochidion brun- } \\
\text { neum }\end{array}$ & Tree & SE Asia & 6200 & - & - & - & - & $\begin{array}{l}\text { Van der Ent et al. } \\
\qquad(2015 f)\end{array}$ \\
\hline Phyllanthaceae & $\begin{array}{l}\text { Glochidion cf. } \\
\text { lanceisepalum }\end{array}$ & Tree & Sabah, Malaysia & 3270 & - & - & - & - & $\begin{array}{l}\text { Van der Ent et al. } \\
\qquad(2015 f)\end{array}$ \\
\hline Phyllanthaceae & $\begin{array}{l}\text { Glochidion cf. } \\
\text { mindorense }\end{array}$ & Tree & SE Asia & 2280 & - & - & - & - & $\begin{array}{l}\text { Van der Ent et al. } \\
\qquad(2015 f)\end{array}$ \\
\hline Phyllanthaceae & $\begin{array}{l}\text { Glochidion cf. } \\
\text { rubrum }\end{array}$ & Tree & SE Asia & 7000 & - & - & - & - & $\begin{array}{l}\text { Van der Ent et al. } \\
\qquad(2015 f)\end{array}$ \\
\hline Phyllanthaceae & $\begin{array}{l}\text { Glochidion cf. } \\
\text { sericeum }\end{array}$ & Tree & Sabah, Malaysia & 2190 & - & 1310 & - & - & $\begin{array}{l}\text { Van der Ent et al. } \\
\text { (2015f); Van der } \\
\text { Ent (unpublished }\end{array}$ \\
\hline Phyllanthaceae & $\begin{array}{l}\text { Glochidion sp. } \\
\text { 'bambangan' }\end{array}$ & Tree & Sabah, Malaysia & 16,700 & - & - & - & - & $\begin{array}{l}\text { Van der Ent et al. } \\
\quad(2015 f)\end{array}$ \\
\hline
\end{tabular}


Table 4 continued

\begin{tabular}{|c|c|c|c|c|c|c|c|c|c|}
\hline Family & Species & Life-form & Locality & $\mathrm{Ni}$ & $\mathrm{Cu}$ & Co & Mn & $\mathrm{Zn}$ & Reference \\
\hline Phyllanthaceae & $\begin{array}{l}\text { Glochidion sp. } \\
\text { 'nalumad' }\end{array}$ & Tree & Sabah, Malaysia & 9000 & - & - & - & - & $\begin{array}{l}\text { Van der Ent et al. } \\
\quad(2015 f)\end{array}$ \\
\hline Phyllanthaceae & $\begin{array}{c}\text { Phyllanthus } \\
\text { balgooyi }\end{array}$ & Tree & $\begin{array}{r}\text { Malaysia and } \\
\text { Philippines }\end{array}$ & 8610 & - & - & - & - & $\begin{array}{l}\text { Hoffmann et al. } \\
\text { (2003), Mesjasz- } \\
\text { Przybylowicz et al. } \\
\text { (2015) }\end{array}$ \\
\hline Phyllanthaceae & $\begin{array}{l}\text { Phyllanthus eryth- } \\
\text { rotrichus }\end{array}$ & Shrub & $\begin{array}{l}\text { Zambales, Philip- } \\
\text { pines }\end{array}$ & 17,520 & - & - & - & - & $\begin{array}{l}\text { Quimado et al. } \\
\qquad(2015)\end{array}$ \\
\hline Phyllanthaceae & $\begin{array}{l}\text { Phyllanthus securi- } \\
\text { negioides }\end{array}$ & Shrub & Sabah, Malaysia & 23,300 & - & - & - & - & $\begin{array}{l}\text { Baker et al. (1992), } \\
\text { Van der Ent et al. } \\
(2015 f)\end{array}$ \\
\hline Phyllanthaceae & $\begin{array}{l}\text { Phyllanthus sp. } \\
\text { undet. }\end{array}$ & Shrub & Sri Lanka & - & 821 & - & - & - & $\begin{array}{l}\text { Rajakaruna and } \\
\text { Bohm (2002) }\end{array}$ \\
\hline Piperaceae & $\begin{array}{l}\text { Peperomia pel- } \\
\text { lucida }\end{array}$ & Shrub & $\begin{array}{l}\text { Sulawesi, Indo- } \\
\text { nesia }\end{array}$ & - & 300 & - & - & - & Brooks et al. (1978) \\
\hline Rubiaceae & $\begin{array}{l}\text { Psychotria cf. } \\
\text { gracilis }\end{array}$ & - & Sabah, Malaysia & 10,590 & - & - & - & - & Reeves (2003) \\
\hline Rubiaceae & $\begin{array}{l}\text { Psychotria sarmen- } \\
\text { tosa }\end{array}$ & Climber & Sabah, Malaysia & 24,200 & - & - & - & - & $\begin{array}{l}\text { Van der Ent et al. } \\
\qquad(2015 f)\end{array}$ \\
\hline Rubiaceae & $\begin{array}{l}\text { Psychotria sp. } \\
\text { undet. }\end{array}$ & - & $\begin{array}{l}\text { Sulawesi, Indo- } \\
\text { nesia }\end{array}$ & 1820 & - & - & - & - & Reeves (2003) \\
\hline Rubiaceae & $\begin{array}{l}\text { Urophyllum cf. } \\
\text { macrophyllum }\end{array}$ & Herb & Sabah, Malaysia & - & - & - & 10,464 & - & $\begin{array}{l}\text { Van der Ent and } \\
\text { Reeves (2015) }\end{array}$ \\
\hline Salicaceae & Flacourtia indica & Tree & Sri Lanka & 1165 & - & - & - & - & Samithri (2015) \\
\hline Salicaceae & $\begin{array}{l}\text { Flacourtia kinabal- } \\
\text { uensis }\end{array}$ & Tree & Sabah, Malaysia & 7280 & - & - & - & - & $\begin{array}{l}\text { Van der Ent et al. } \\
\quad(2015 f)\end{array}$ \\
\hline Salicaceae & Xylosma luzonensis & Tree & SE Asia & 5360 & - & - & - & - & $\begin{array}{l}\text { Van der Ent et al. } \\
\qquad(2015 f)\end{array}$ \\
\hline Sapindaceae & $\begin{array}{l}\text { Mischocarpus } \\
\text { sundaicus }\end{array}$ & Tree & SE Asia & 4425 & - & & - & - & $\begin{array}{l}\text { Van der Ent et al. } \\
\qquad(2015 f)\end{array}$ \\
\hline Sapotaceae & $\begin{array}{l}\text { Planchonella } \\
\text { obovata }\end{array}$ & Tree & $\begin{array}{l}\text { Zambales, Philip- } \\
\text { pines }\end{array}$ & 1005 & - & - & - & - & $\begin{array}{l}\text { Fernando et al. } \\
\text { (2013) }\end{array}$ \\
\hline Sapotaceae & $\begin{array}{l}\text { Planchonella } \\
\text { oxyedra }\end{array}$ & Tree & $\begin{array}{l}\text { Obi Island, Indo- } \\
\text { nesia }\end{array}$ & 19,600 & - & - & - & - & $\begin{array}{l}\text { Wither and Brooks } \\
\text { (1977) }\end{array}$ \\
\hline Tiliaceae & $\begin{array}{l}\text { Trichospermum } \\
\text { kjellbergii }\end{array}$ & Tree & Indonesia & 3770 & - & - & - & - & $\begin{array}{l}\text { Wither and Brooks } \\
\text { (1977) }\end{array}$ \\
\hline Urticaceae & Laportea ruderalis & Herb & $\begin{array}{l}\text { Sulawesi, Indo- } \\
\text { nesia }\end{array}$ & - & 600 & - & - & - & Brooks et al. (1978) \\
\hline Verbenaceae & $\begin{array}{l}\text { Callicarpa sp. } \\
\text { undet. }\end{array}$ & Shrub & $\begin{array}{l}\text { Zambales, Philip- } \\
\text { pines }\end{array}$ & 1052 & - & - & - & - & $\begin{array}{l}\text { Fernando et al. } \\
\text { (2013) }\end{array}$ \\
\hline Violaceae & $\begin{array}{l}\text { Hybanthus enneas- } \\
\text { permus }\end{array}$ & Shrub & Sri Lanka & 1862 & - & - & - & - & $\begin{array}{l}\text { Rajakaruna and } \\
\text { Bohm (2002) }\end{array}$ \\
\hline Violaceae & $\begin{array}{l}\text { Rinorea benga- } \\
\text { lensis }\end{array}$ & Tree & $\begin{array}{l}\text { S \& SE Asia and } \\
\text { Australia }\end{array}$ & $2723-18,840$ & - & - & - & - & $\begin{array}{l}\text { Brooks and Wither } \\
\text { (1977); Datta et al. } \\
(2015)\end{array}$ \\
\hline Violaceae & Rinorea javanica & Tree & SE Asia & 9680 & - & - & - & - & $\begin{array}{l}\text { Brooks and Wither } \\
\text { (1977) }\end{array}$ \\
\hline Violaceae & Rinorea niccolifera & Shrub & $\begin{array}{l}\text { Luzon Island, } \\
\text { Philippines }\end{array}$ & 18,388 & - & - & - & - & $\begin{array}{l}\text { Fernando et al. } \\
\text { (2014) }\end{array}$ \\
\hline Violaceae & Rinorea sp. nov. & Shrub & $\begin{array}{l}\text { Talaud Island, } \\
\text { Indonesia }\end{array}$ & 1830 & - & - & - & - & Proctor et al. (1994) \\
\hline
\end{tabular}

further observations and additional greenhouse studies to determine whether the ultramafic-associated populations are genetically distinct and are worthy of ecotypic recognition (Rajakaruna and Bohm 2002). These taxa include several $\mathrm{Ni}$-accumulating and -hyperaccumulating species, particularly Hybanthus enneaspermus (Violaceae), Evolvulus alsinoides (Convolvulaceae), Crotalaria sp. (Fabaceae), Desmodium triflorum (Fabaceae) and 
Fimbristylis sp. (Cyperaceae), all of which show detectable phenotypic differences between ultramafic and nonultramafic populations. Studies exploring causes and consequences of phenotypic differences between populations found on and off ultramafic soils can add much to our understanding of the origins of ultramafic specialists in the South and Southeast Asia region.

\section{Phytotechnologies}

The use of trace element hyperaccumulators to clean up polluted sites, i.e. phytoremediation, is gaining recognition as a viable green technology (Neilson and Rajakaruna 2014). Phytoremediation is based on the premise that plants which remove selected pollutants from the soil and translocate them to their above-ground biomass can then be harvested and disposed of through incineration or elemental recovery, a process known as phytomining (Chaney et al. 2014; van der Ent et al. 2015g). Ultramafic plants in the genera Alyssum (Brassicaceae), Streptanthus (Brassicaceae), Noccaea (Brassicaceae), and Berkheya (Asteraceae) have been used in phytoremediation and phytomining of Ni-enriched ultramafic sites in temperate and Mediterranean regions (Ho et al. 2013; Morel et al. 2006; Gall and Rajakaruna 2013; Sheoran et al. 2009; van der Ent et al. 2015g). Given the large number of hyperaccumulator species currently known from tropical Asia (Gall and Rajakaruna 2013; Reeves 2003), there should be considerable interest in using these unique plants in the remediation of regional sites contaminated with metal and metalloid pollutants.

\section{Phytoremediation and phytomining}

Bandara et al. (2017) investigated the effect of biochar and fungal-bacterial co-inoculation on soil enzymatic activity and immobilization of heavy metals in soil collected from an ultramafic outcrop in Sri Lanka. The addition of biochar to ultramafic soil immobilized heavy metals and decreased soil enzymatic activities while the addition of microbial inoculants improved plant growth by mitigating heavy metal toxicity and enhancing soil enzymatic activities. Additional studies from Sri Lanka confirm the importance of (i) bacterial-fungal inoculation as a soil-quality enhancer and a plant-growth promoter in the presence of heavy metals found in ultramafic soils (Seneviratne et al. 2016a, b), and, (ii) biochar as a soil amendment to immobilize $\mathrm{Cr}, \mathrm{Ni}$, and $\mathrm{Mn}$ in ultramafic soil, thereby reducing metal-induced plant toxicities (Herath et al. 2014).

The potential for microbial remediation (reduction) of $\mathrm{Cr}(\mathrm{VI})$ by indigenous microbial populations from the ultramafic soils of Sukinda mines in Jaipur, Orissa, India, was investigated by Mishra et al. (2009). The best reducer of Cr (V1) was Staphylococcus aureus, a gram-positive bacterium whose thick layer of peptidoglycan acts as a strong absorbent. The taxon tolerated a $\mathrm{Cr}$ concentration of $250 \mathrm{mg} \mathrm{L}^{-1}$ and was resistant to $\mathrm{Ni}$ up to $1000 \mathrm{mg} \mathrm{L}^{-1}$. The bacterium was recommended for the bioremediation of both $\mathrm{Cr}$ and $\mathrm{Ni}$, showing complete $\mathrm{Cr}(\mathrm{VI})$ to $\mathrm{Cr}(\mathrm{III})$ degradation in $22 \mathrm{~h}$, and $\mathrm{Ni}^{2+}$ degradation to $90 \%$ in $22 \mathrm{~h}$. Similarly, Bohidar et al. (2009) explored the possibility of Ni recovery from chromite tailings at the Sukinda mines by using three fungal strains.

In another study, Mohanty et al. (2011) utilized phytoremediation in South Kaliapani, a chromite mining ultramafic area in Orissa, India. Chromium was extracted by growing Oryza sativa cv. Khandagiri (rice; Poaceae) in contaminated soil and irrigating with mine wastewater. Chromium levels were reduced (70-90\%) after 100 days, with accumulation levels ranging from 125 to $498 \mu \mathrm{g} \mathrm{g}^{-1}$ in leaves, 25 to $400 \mu \mathrm{g} \mathrm{g}^{-1}$ in stems, and 5 to $23 \mu \mathrm{g} \mathrm{g}^{-1}$ in the grain. Absorption into roots was higher by two orders of magnitude than into any aerial part of the plant. Mohanty et al. (2012) also investigated the phytoremediation potential of O. sativa, Brachiaria mutica (Poaceae), and Eichhornia crassipes (Pontederiaceae) to reduce levels of $\mathrm{Cr}(\mathrm{VI})$ in mine waste-water. Eichhornia crassipes was most successful with $25-54 \%$ reduction while $B$. mutica contributed to an $18-33 \%$ reduction.

Kfayatullah et al. (2001), in a study of plants and soils of the Malakand chromite-rich ultramafic area and Mardan non-ultramafic areas of the North-West Frontier Province, Pakistan, focused on enzyme-bound metal accumulation in plant tissue. Verbascum thapsus (Scrophulariaceae), an edible plant, accumulated greater than $100 \mu \mathrm{g} \mathrm{g}^{-1}$ of several metals, including $\mathrm{Ni}$ and $\mathrm{Cr}$, but was not recommended for phytoremediation efforts.

Indonesia (Sulawesi and Halmahera Islands) has some of the largest surface exposures of ultramafic bedrock in the world. Lateritic Ni-mining operations have continued in the region since the early twentieth century, setting the stage for exploring the use of native plants for phytoremediation and phytomining. Twelve native species known to hyperaccumulate $\mathrm{Ni}$ are recommended by van der Ent et al. (2013a) for use in phytotechnologies in Indonesia.

\section{Threats and conservation}

Ultramafic areas are a high priority for biodiversity conservation because of the relatively large numbers of endemic species, ecotypes, and rare species that they harbour (Boyd et al. 2009). The conservation and restoration of these naturally fragmented, edaphically unique, and biodiverse habitats require special attention (Baker et al. 2010; O'Dell 2014; Thorne et al. 2011; Whiting et al. 2004). It is unclear how stressors, such as atmospheric $\mathrm{N}$ deposition (Vallano et al. 2012), suppression of fire 
(Arabas 2000; Safford and Harrison 2004) and climate change (Damschen et al. 2012; Anacker and Harrison 2012) documented for temperate and Mediterranean ultramafics, impact tropical Asia's ultramafic ecosystems.

The combined forces of forest clearing, agricultural development and mining contribute to unprecedented habitat loss in South and Southeast Asia (Duckworth et al. 2012; Hughes 2017; Sodhi et al. 2004). In fact, Southeast Asia has a higher annual rate of deforestation than Meso-America, South America, or sub-Saharan Africa, and that rate has continued to increase between 1990 and 2005 (Giam et al. 2010; Sodhi et al. 2010). This is especially of concern as Southeast Asia has a higher proportion of its vascular plant, reptile, bird, and mammal species categorised as globally threatened on the Red List compared to Meso- and South America and sub-Saharan Africa (Sodhi et al. 2010). With such limited study of ultramafics in South and Southeast Asia, it is unclear how increasing habitat loss is impacting biodiverse ultramafic outcrops in the region.

Malaysia has one of the most species-rich ultramafic floras in the world. The over $3500 \mathrm{~km}^{2}$ of ultramafic outcrops in Sabah (4.6\% of the total landmass of the state) on the island of Borneo harbor a total of 4252 plant species (van der Ent et al. 2015a). Over 2542 plant species have been documented on ultramafic outcrops in Kinabalu Park alone, of which a large percentage is endemic to either Kinabalu Park or to Borneo (van der Ent et al. 2015a; Fig. 4). Despite the existence of this species-rich flora, the plant diversity and ecology of many ultramafic outcrops in Sabah remain largely unknown because of a lack of focused research. Furthermore, plant diversity in many areas of Sabah is severely threatened by land-use conversion and, because often plant species occur only at a single or a few ultramafic sites, and hence impacts on the ecosystems that support them could eventually result in their extinction. While it is necessary to identify stressors impacting ultramafic habitats of South and Southeast Asia for their proper management, it is even more critical that basic geoecological surveys of ultramafic outcrops, including the extensive exposures in Sulawesi and Halmahera, are prioritised for cataloguing plant diversity and other biota. This is especially critical as many of these outcrops likely harbor rare and endemic species in need of urgent conservation attention.

Although Sri Lanka's ultramafic flora appears to be impoverished with respect to endemic species or hyperaccumulator taxa, the ultramafic sites harbor several taxa worthy of conservation. For example, Ussangoda, the site that has received the most research attention, is home to: four near-threatened species, Striga angustifolia (Orobanchaceae), Maerua arenaria (Capparaceae), Salvadora percia (Salvadoraceae), and Olax imbricata
(Olacaceae); two vulnerable species, Cyanotis adscendens (Commelinaceae), Pachygone ovata (Menispermaceae); and one data deficient species, Alysicarpus monilifer (Fabaceae; MOE 2012). Therefore, it is critical that Sri Lanka's ultramafic outcrops receive regional and national recognition and are declared as ecologically sensitive sites (i.e. geoecological preserves) to be set aside for future investigations. In 2010, Ussangoda was declared as a National Park with approximately 350 hectares, including areas overlaying ultramafic rock, set aside for conservation purposes (Department of Wildlife Conservation 2015). Without such conservation, proper management, and research, these unique habitats and their physiologically distinct biota are extremely vulnerable. Rinorea bengalensis (Violaceae) offers an example of why such efforts are urgently needed. Brooks et al. (1977a, b) conducted a survey of herbarium specimens from the entire range of this species, encompassing Sri Lanka, the Malay Archipelago, New Guinea, the Solomon Islands and Queensland, Australia, and found that Ni hyperaccumulation is a constitutive trait in this species when growing on ultramafic soil. The herbarium specimen analysed from Sri Lanka contained 10,000 $\mu \mathrm{g} \mathrm{g}^{-1}$ and the locality indicated on the map presented by Brooks et al. (1977a) suggests a collection in the central part of the island (see Fig. 1 in Rajakaruna and Baker 2004). However, it was not encountered in field exploration by Rajakaruna and Bohm (2002) and was presumed extinct in Sri Lanka (Ministry of Environment and Renewable Energy 2012). Interestingly, the taxon was recently recollected in southwestern Sri Lanka (Siril Wijesundara, National Institute of Fundamental Studies, Sri Lanka, pers. comm.), however, soil and plant tissue elemental concentrations have yet to be determined.

\section{Conclusions}

\section{Information gaps and future directions}

Ultramafic outcrops are natural laboratories for experimental and applied research in a wide range of disciplines. They provide numerous opportunities for collaborations among geologists, pedologists, botanists, zoologists, microbiologists, and land managers focusing on conservation and restoration research. However, research on the ultramafic outcrops in South and Southeast Asia has been limited, with most effort to date focused on Malaysia, the Philippines, the Andaman Islands (India), and Sri Lanka (Table 1). We were unable to find any published literature on ultramafic geoecology of other South (Afghanistan, Bhutan, Nepal) and Southeast Asian (Myanmar, Laos, Thailand, Vietnam) countries despite the known occurrences of ultramafic lithologies in these locales. The limited number of published studies we found for Myanmar, Thailand, and Vietnam 
(Table 1) focused on geological, mineralogical, or geochemical research.

Throughout South and Southeast Asia, detailed and systematic surveys will likely reveal numerous species new to science, including trace element hyperaccumulators. Recent research conducted in Sabah, Malaysia by van der Ent et al. (2014, 2015a, f) which led to the discovery of 24 new hyperaccumulator species, is a case in point. Detailed floristic surveys should be undertaken across the region and species showing unusual physiological behavior (such as trace element accumulation) or exhibiting distinct morphological traits relative to populations on non-ultramafic soils may be further studied under laboratory and greenhouse conditions. Additionally, species showing intraspecific variation between ultramafic and non-ultramafic populations may be evaluated via population genetic studies to determine whether ultramafic populations are genetically distinct from those found on non-ultramafic soils. For those species showing intraspecific variation with respect to morphological or physiological features, including flowering times between ultramafic and nonultramafic populations, common garden and reciprocal transplant experiments can be undertaken to examine whether populations are locally adapted to their substrate. Such types of experimental studies are currently lacking entirely from the region.

In addition to detailed studies of vascular plants, it is important to pay close attention to non-vascular plants such as bryophytes, cryptogamic species such as lichens, soil algae and cyanoprokaryotes, and belowground microbes and soil invertebrates. Such investigations will likely reveal species that are endemic to the substrate or show a high affinity to ultramafic soils, as shown for such research conducted in South Africa (Venter et al. 2015) and California, USA (Rajakaruna et al. 2012).

Species documented as trace element hyperaccumulators may be investigated under controlled conditions for their suitability for phytoremediation or phytomining and tested under field conditions for their effectiveness in site reclamation and restoration. The resulting information can be added to the global database of metal hyperaccumulating species (Global Hyperaccumulator Database 2016: http://www.hyperaccumulators.org). Finally, it is critical that tropical Asia's ultramafic outcrops receive regional, national, and global recognition and that key sites receive appropriate statutory protection so that future scientific research is possible.

One of the options for protection at a national level by the state is the inclusion of ultramafic sites in the Global Geopark Network (GGN). Conservation and protection of landscapes of geological significance at a national and international level is promoted by UNESCO under its
Global Geoparks Scheme (UNESCO 2016). At a national level, relevant authorities should pursue this option as a long-term conservation strategy, which would provide a holistic approach to protection by incorporating a management strategy including education and sustainable development. The latter would mobilize the local population for economic benefits by participating in the conservation efforts through local and international ecotourism. This, however, also requires meeting the stringent guidelines laid out by UNESCO to be included in the GGN. Currently, ultramafic sites in South and Southeast Asia are not in the GGN but would meet the basic requirements laid out by UNESCO.

\section{Authors' contributions}

Conceptualization, NR, AE, MCMl; writing original manuscript draft, MLG; writing and editing, NR, AE, MCMI; visualization, MLG, AE, NR. All authors read and approved the final manuscript.

\section{Author details}

${ }^{1}$ Center for Water and Environment, Natural Resources Research Institute, University of Minnesota, Duluth, MN 55811, USA. ${ }^{2}$ Centre for Mined Land Rehabilitation, Sustainable Minerals Institute, The University of Queensland, Brisbane, QLD, Australia. ${ }^{3}$ Laboratoire Sols et Environnement, Université de Lorraine-INRA, UMR 1120, Nancy, France. ${ }^{4}$ Plant Biology Laboratory, National Institute of Fundamental Studies, Kandy 20000, Sri Lanka. ${ }^{5}$ Biological Sciences Department, California Polytechnic State University, San Luis Obispo, CA 93407, USA. ${ }^{6}$ Unit for Environmental Sciences and Management, North-West University, Potchefstroom 2520, South Africa.

\section{Acknowledgements}

A. van der Ent is the recipient of a Discovery Early Career Researcher Award (DE160100429) from the Australian Research Council. The French National Research Agency through the national "Investissements d'avenir" program (ANR-10-LABX-21, LABEX RESSOURCES21) and through the ANR-14-CE04-0005 Project "Agromine" is acknowledged for funding support to A. van der Ent. N. Rajakaruna is supported by a US Research Scholar Fulbright Award for 2016-2017 and the National Institute of Fundamental Studies, Kandy, Sri Lanka. We would like to thank lan Medeiros for his constructive comments on an earlier draft of this manuscript.

\section{Competing interests}

The authors declare that they have no competing interests.

Received: 28 October 2016 Accepted: 1 March 2017

Published online: 03 April 2017

\section{References}

Acharya C, Kar R, Sukla L (1998) Short communication: leaching of chromite overburden with various native bacterial strains. World J Microbiol Biotechnol 14:769-771. doi:10.1023/A:1008888031842

Adam JH (2002) Demographic study of Nepenthes species (Nepenthaceae) recorded along the trail to the summit of Mount Kinabalu in Sabah, Malaysia. Pak J Biol Sci 5:419-426

Aggangan NS, Dell B, Malajczuk N (1998) Effects of chromium and nickel on growth of the ectomycorrhizal fungus Pisolithus and formation of ectomycorrhizas on Eucalyptus urophylla S.T. Blake. Geoderma 84:15-27. doi:10.1016/S0016-7061(97)00118-3

Aiba S, Kitayama K (1999) Structure, composition and species diversity in an altitude-substrate matrix of rain forest tree communities on Mount Kinabalu, Borneo. Plant Ecol 140:139-157. doi:10.102 3/A:1009710618040

Aiba S-I, Sawada Y, Takyu M, Seino T, Kitayama K, Repin R (2015) Structure, floristics and diversity of tropical montane rain forests over ultramafic soils 
on Mount Kinabalu (Borneo) compared with those on non-ultramafic soils. Aust J Bot 63(4):191-203. doi:10.1071/BT14238

Alexander EB (2009) Soil and vegetation differences from peridotite to serpentinite. Northeast Nat 16(5):178-192. doi:10.1656/045.016.0515

Alexander EB, DuShey J (2011) Topographic and soil differences from peridotite to serpentinite. Geomorphology 135(3-4):271-276. doi:10.1016/j. geomorph.2011.02.007

Alexander EB, Coleman RG, Keeler-WolfT, Harrison SP (2007) Serpentine geoecology of Western North America: geology, soils, and vegetation. Oxford University Press, New York

Anacker BL (2011) Phylogenetic patterns of endemism and diversity. In: Harrison SP, Rajakaruna N (eds) Serpentine: the evolution and ecology of a model system. University of California Press, Berkeley

Anacker BL (2014) The nature of serpentine endemism. Am J Bot 101:219-224. doi:10.3732/ajb.1300349

Anacker BL, Harrison SP (2012) Climate and the evolution of serpentine endemism in California. Evol Ecol 26:1011-1023. doi:10.1007/ s10682-011-9532-4

Anacker BL, Whittall JB, Goldberg EE, Harrison SP (2011) Origins and consequences of serpentine endemism in the California flora. Evolution 65:365-376. doi:10.1111/j.1558-5646.2010.01114.x

Arabas KB (2000) Spatial and temporal relationships among fire frequency, vegetation, and soil depth in an eastern North American serpentine barren. JTorrey Bot Soc 127:51-65

Argent G, Wilkie P, Maduli D (2007) Lobelia proctorii sp. nov. (Lobelioideae, Campanulaceae/Lobeliaceae) from the Philippines. Plant Ecol 192:157-160. doi:10.1007/s11258-007-9306-9

Arnold BA, Lahner B, DaCosta J, Weisman C, Hollister J, Salt D, Bomblies $\mathrm{K}$, Yant L (2016) Borrowed alleles and convergence in serpentine adaptation. Proc Natl Acad Sci USA 113:8320-8325. doi:10.1073/ pnas. 1600405113

Baker AJM, Proctor J, Van Balgooy MMJ, Reeves RD (1992) Hyperaccumulation of nickel by the flora of the ultramafics of Palawan, Republic of the Philippines. In: Baker AJM, Proctor J, Reeves RD (eds) The vegetation of ultramafic (Serpentine) soils: proceedings of the first international conference on serpentine ecology. Intercept Ltd., Andover

Baker AJM, Ernst WHO, Van der Ent A, Malaisse F, Ginocchio R (2010) Metallophytes: the unique biological resource, its ecology and conservational status in Europe, central Africa and Latin America. In: Batty LC, Hallberg KB (eds) Ecology of industrial pollution. Ecological Reviews. Cambridge University Press, Cambridge

Baklanov IA (2011) Heterogeneity of epidermal cells in relation to nickel accumulation in hyperaccumulator plants belonging to the genus Alyssum L. Cell Tissue Biol 5:603-611. doi:10.1134/S1990519X11060034

Baldwin BG (2005) Origin of the serpentine-endemic herb Layia discoidea from the widespread L. glandulosa (Compositae). Evolution 59:2473-2479. doi:10.1111/j.0014-3820.2005.tb00956.x

Bandara T, Herath I, Kumarathilaka P, Seneviratne M, Seneviratne G, Rajakaruna N, Vithanage M (2017) Role of woody biochar and fungal-bacterial co-inoculation on soil enzyme activity and heavy metal immobilization in serpentine soil. J Soils Sediments 17:665-673. doi:10.1007/ s11368-015-1243-y.

Banerjee PK (1972) Geology and geochemistry of the Sukinda ultramafic field, Cuttack district. Orissa Mem Geol Surv India 103:1-158

Barthlott W, Hostert A, Kier G, Küper W, Kreft H, Mutke J, Rafiqpoor MD, Sommer JH (2007) Geographic patterns of vascular plant diversity at continental to global scales. Erdkunde 61(4):305-315. doi:10.3112/ erdkunde.2007.04.01

Batianoff GN, Specht RL (1992) Queensland (Australia) serpentinite vegetation. In: Proctor J, Baker AJM, Reeves RD (eds) The vegetation of ultramafic (serpentine) soils. Intercept Ltd, Andover, UK, pp 109-128

Batianoff GN, Singh S (2001) Central Queensland serpentine landforms, plant ecology and endemism. S Afr J Sci 97:495-500

Batten KM, Scow KM, Davies KF, Harrison SP (2006) Two invasive plants alter soil microbial community composition in serpentine grasslands. Biol Invasions 8:217-230. doi:10.1007/s10530-004-3856-8

Bhatia NP, Walsh KB, Orlic I, Siegele R, Ashwath N, Baker AJM (2004) Studies on spatial distribution of nickel in leaves and stems of the metal hyperaccumulator Stackhousia tryonii Bailey using nuclear microprobe (microPIXE) and EDXS techniques. Funct Plant Biol 31:1061-1074
Bhatta K, Ghosh B (2014) Chromian spinel-rich black sands from eastern shoreline of Andaman Island, India: implication for source characteristics. J Earth Syst Sci 123:1387-1397. doi:10.1007/s12040-014-0474-4

Biswas S, Saikat S, Dey R, Mukherjee S, Banerjee PC (2013) Microbial leaching of chromite overburden from Sukinda mines, Orissa, India using Aspergillus niger. Int J Miner Metall Mater 20:705-712. doi:10.1007/s12613-013-0787-3

Bohidar S, Mohapatra S, Sukla LB (2009) Nickel recovery from chromite overburden of Sukinda using fungal strains. Int J Integr Biol 5:103-108

Borhidi A (1992) The serpentine flora and vegetation of Cuba. In: Baker AJM, Proctor J, Reeves RD (eds) The vegetation of ultramafic (Serpentine) soils. Proc. 1st international conference on serpentine ecology. Intercept Ltd., Andover

Boyd RS (2009) High-nickel insects and nickel hyperaccumulator plants: a review. Insect Sci 16(1):19-31. doi:10.1111/j.1744-7917.2009.00250.x

Boyd RS (2014) Ecology and evolution of metal-hyperaccumulating plants. In: Rajakaruna N, Boyd RS, Harris TB (eds) Plant ecology and evolution in harsh environment. Nova Science Publishers, Hauppauge

Boyd RS, Kruckeberg AR, Rajakaruna N (2009) Biology of ultramafic rocks and soils: research goals for the future. Northeast Nat 16(5):422-440. doi:10.1656/045.016.0530

Brady KU, Kruckeberg AR, Bradshaw HD (2005) Evolutionary ecology of plant adaptation to ultramafic soils. Annu Rev Ecol Evol Syst 36:243-266. doi:10.1146/annurev.ecolsys.35.021103.105730

Bratteler M, Lexer C, Widmer A (2006) Genetic architecture of traits associated with serpentine adaptation of Silene vulgaris. J Evol Biol 19:1149-1156. doi:10.1111/j.1420-9101.2006.01090.x

Brearley FQ (2005) Nutrient limitation in a Malaysian ultramafic soil. J Trop For Sci 17:596-609

Briscoe LRE, Harris TB, Dannenberg E, Broussard W, Olday FC, Rajakaruna N (2009) Bryophytes of adjacent serpentine and granite outcrops on the Deer Isles, Maine, USA. Rhodora 111:1-20. doi:10.3119/07-31.1

Broadhurst CL, Chaney RL, Angle JS, Erbe EF, Maugel TK (2004) Nickel localization and response to increasing Ni soil levels in leaves of the Ni hyperaccumulator Alyssum murale. Plant Soil 265:225-242

Brooks RR (1987) Serpentine and its vegetation: a multidisciplinary approach. Dioscorides Press, Portland

Brooks RR, Wither ED (1977) Nickel hyperaccumulation by Rinorea bengalensis (Wall.) O.K. J Geochem Explor 7:295-300. doi:10.1016/0375-6742(77)90085-1

Brooks RR, Wither ED, Zepernick B (1977a) Cobalt and nickel in Rinorea species. Plant Soil 47:707-712. doi:10.1007/BF00011041

Brooks RR, Lee J, Reeves RD, Jaffré T (1977b) Detection of nickeliferous rocks by analysis of herbarium specimens of indicator plants. J Geochem Explor 7:49-57. doi:10.1016/0375-6742(77)90074-7

Brooks RR, Wither ED, Westra LY (1978) Biogeochemical copper anomalies on Salajar Island Indonesia. J Geochem Explor 10:181-188. doi:10.1016/0375-6742(78)90017-1

Bruijnzeel LA (1990) Soil moisture regime as a major factor determining vegetation structure on ultramafic soils in Palawan, the Philippines, and Sabah, Malaysia. Act Bot Need 39:402

Bruijnzeel LA, Waterloo MJ, Proctor J, Kuiters AT, Kotterink B (1993) Hydrological observations in montane rain forests on Gunung Silam, Sabah, Malaysia, with special reference to the 'Massenerhebung' effect. J Ecol 81:145-167

Burge DO, Thorne JH, Harrison SP, O'Brien BC, Shevock JR, Alverson ER, Hardison LK, Delgadillo J, Junak S, Oberbauer T, Rebman JP, Riemann H, Vanderplank SE, Barry T (2016) Plant diversity and endemism in the California Floristic Province. Madroño 63(2):3-206. doi:10.3120/ madr-63-02-3-206.1

Cardace D, Meyer-Dombard DR, Olsen AA, Parenteau MN (2014) Bedrock and geochemical controls on extremophile habitats. In: Rajakaruna N, Boyd RS, Harris TB (eds) Plant ecology and evolution in harsh environments. Nova Science Publishers, Hauppauge

Central Energy Resources Team (1999) Generalized Geology of the Far East (geo3al), US Geological Survey. https://catalog.data.gov/dataset/generalized-geology-of-the-far-east-geo3al. Accessed 12 Oct 2016

Chakraborty KL, Chakraborty TL (1984) Geological features and origin of the chromite deposits of Sukinda Valley, Orissa, India. Miner Deposita 19:256-265. doi:10.1007/BF00204378

Chaney RL, Reeves RD, Baklanov IA, Centofanti T, Broadhurst CL, Baker AJM, Van der Ent A, Roseberg RJ (2014) Phytoremediation and phytomining: using plants to remediate contaminated or mineralized environments. 
In: Rajakaruna N, Boyd RS, Harris TB (eds) Plant ecology and evolution in harsh environment. Nova Science Publishers, Hauppauge

Chathuranga PKD, Dharmasena SKAT, Rajakaruna N, Iqbal MCM (2015) Growth and nickel uptake by serpentine and non-serpentine populations of Fimbristylis ovata (Cyperaceae) from Sri Lanka. Aust J Bot 63:128-133. doi:10.1071/BT14232

Chaudhury K, Datta S, Mukherjee PK (2015) Mapping the vegetation of the ultramafic outcrops of Saddle Hills (North Andaman Islands, India) using remote-sensing tools. Aust J Bot 63:234-242. doi:10.1071/ BT14243

Cheek M (2015) Nepenthes (Nepenthaceae) of Halmahera, Indonesia. Blumea 59:215-225. doi:10.3767/000651915X689091

Chen J, Wong KM, Van der Ent A, Tan HTW (2014) Nine new species of Timonius (Rubiaceae) from Kinabalu Park, Borneo. Phytotaxa 181:138-150. doi:10.11646/phytotaxa.181.3.2

Chung AYC, Chew SKF, Majapun R, Nilus R (2013) Insect diversity of Bukit Hampuan Forest Reserve, Sabah, Malaysia. J Threat Taxa 5:4461-4473

Damschen El, Harrison SP, Ackerly DD, Fernandez-Going BM, Anacker BL (2012) Endemic plant communities on special soils: early victims or hardy survivors of climate change? J Ecol 100:1122-1130. doi:10.1111/j.1365-2745.2012.01986.x

Datta S, Chaudhury K, Mukherjee PK (2015) Hyperaccumulators from the serpentines of Andaman, India. Aust J Bot 63:243-251. doi:10.1071/ BT14244

Davis S, Heywood VH (eds) (1995) Centres of plant diversity, volume 2: Asia, Australasia and the Pacific. International Union for the Conservation of Nature and Natural Resources, p 578

Department of Wildlife Conservation (2015) National Parks. http://www.dwc gov.lk/index.php/en/national-parks. Accessed 27 Oct 2016

Dhakate R, Singh VS (2008) Heavy metal contamination in groundwater due to mining activities in Sukinda Valley, Orissa—a case study. J Geogr Reg Plann 1:48-67

Dissanayaka CB (1982) The geology and geochemistry of the Uda Walawe serpentinite. Sri Lanka. J Natn Sci Coun Sri Lanka 10:13-34

Dissanayake CB, Van Riel BJ (1978) The petrology and geochemistry of a recently discovered nickeliferous serpentinite from Sri Lanka. J Geol Soc India 19:464-471

Duckworth JW, Batters G, Belant JL, Bennett EL, Brunner J, et al. (2012) Why South-east Asia should be the world's priority for averting imminent species extinctions, and a call to join a developing cross-institutional programme to tackle this urgent issue. S.A.P.I.E.N.S 5(2). http://sapiens. revues.org/1327. Accessed 12 Oct 2016

Elam DR, Wright DH, Goettle B (1998) Recovery plan for serpentine soil species of the San Francisco Bay Area. US Fish and Wildlife Service, Region 1 , Portland, OR

Favero-Longo SE, Isocrono D, Piervittori R (2004) Lichens and ultramafic rocks: a review. Lichenologist 36:391-404. doi:10.1017/S0024282904014215

Fernando ES, Rodda M (2013) Marsdenia purpurella (Apocynaceae, Asclepiadoideae), a new species from the Philippines. Gard Bull 65:143-148

Fernando ES, Suh MH, Lee J, Lee DK (2008) Forest formations of the Philippines. ASEAN-Korea Environmental Cooperation Unit, Seoul National University, Seoul, pp 1-232

Fernando ES, Quimado MO, Trinidad LC, Doronila Al (2013) The potential use of indigenous nickel hyperaccumulators for small scale mining in the Philippines. J Degrad Min Land Manag 1:21-26

Fernando ES, Quimado MO, Doronila Al (2014) Rinorea niccolifera (Violaceae), a new, nickel-hyperaccumulating species from Luzon Island, Philippines. Phytokeys 37:1-13. doi:10.3897/phytokeys.37.7136

Fleischmann A, Robinson A, Mcpherson S, Heinrich V, Gironella E, Madulid DA (2011) Drosera ultramafica (Droseraceae), a new sundew species of the ultramafic flora of the Malesian highlands. Blumea 56:10-15. doi:10.376 7/000651911X560907

Fowlie JA (1985) Malaya revisited XXIX, rediscovering the habitat of Paphiopedilum dayanum on serpentine cliffs on Mount Kinabalu in Eastern Malaysia (Formerly North Borneo). Orchid Digest 49:124-129

Fujii K, Hartono A, Funakawa S, Uemuraa M, Sukartiningsih Kosaki T (2011) Acidification of tropical forest soils derived ultramafic and sedimentary rocks in East Kalimantan, Indonesia. Geoderma 160(3-4):311-323. doi:10.1016/j.geoderma.2010.09.027

Gall JE, Rajakaruna N (2013) The physiology, functional genomics, and applied ecology of heavy metal-tolerant Brassicaceae. In: Lang M (ed)
Brassicaceae: characterization, functional genomics and health benefits. Nova Science Publishers Inc, Hauppauge

Ghosh S, Paul AK (2015) Heterotrophic leaching of metals from Indian chromite mining overburden. Int J Min Reclam Environ 1-12. doi: 10.1080/17480930.2015.1118181

Giam X, Ng TH, Yap VB, Tan HTW (2010) The extent of undiscovered species in Southeast Asia. Biodivers Conserv 19:943-954. doi:10.1007/ s10531-010-9792-2

Global Hyperaccumulator Database (2016) http://hyperaccumulators.smi. uq.edu.au/collection/. Accessed 27 Oct 2016

Gotera KC, Doronila Al, Claveria RJR, Perez TR et al (2014) Breynia cernua (Poir.) Müll. Arg. (Phyllanthaceae) is a hyperaccumulator of nickel. Asia Life Sci 23:231-241

Hanson B, Lindblom SD, Loeffler ML, Pilon-Smits EAH (2004) Selenium protects plants from phloem-feeding aphids due to both deterrence and toxicity. New Phytol 162:655-662. doi:10.1111/j.1469-8137.2004.01067.x

Harrison SP, Rajakaruna N (eds) (2011) Serpentine: evolution and ecology in a model system. University of California Press, Berkeley

Harrison SP, Damschen E, Going BM (2009) Climate gradients, climate change, and special edaphic floras. Northeast Nat 16(5):121-130. doi:10.1656/045.016.0510

Hasegawa M, Ito MT, Kitayama K (2006) Community structure of oribatid mites in relation to elevation and geology on the slope of Mount Kinabalu, Sabah, Malaysia. Eur J Soil Biol 42:S191-S196. doi:10.1016/j. ejsobi.2006.07.006

Herath I, Kumarathilaka P, Navaratne A, Rajakaruna N, Vithanage M (2014) Immobilization and phytotoxicity reduction of heavy metals in serpentine soil using biochar. J Soils Sediments 15:126-138. doi:10.1007/ s11368-014-0967-4

Hewawasam T, Fernando GWAR, Priyashantha D (2014) Geo-vegetation mapping and soil geochemical characteristics of the Indikolapelessa serpentinite outcrop, southern Sri Lanka. J Earth Sci 25:152-168. doi:10.1007/ s12583-014-0409-7

Hisada K, Sugiyama M, Ueno K, Charusiri P, Arai S (2004) Missing ophiolitic rocks along the Mae Yuam Fault as the GondwanaTethys divide in north-west Thailand. Island Arc 13:119-127. doi:10.1111/j.1440-1738.2003.00412.x

Ho C-P, Hseu Z-Y, Chen N-C, Tsai C-C (2013) Evaluating heavy metal concentration of plants on a serpentine site for phytoremediation applications. Environ Earth Sci 70:191-199. doi:10.1007/ s12665-012-2115-z

Hoffmann P, Baker AJM, Madulid DA, Proctor J (2003) Phyllanthus balgooyi (Euphorbiaceae s.l.), a new nickel-hyperaccumulating species from Palawan and Sabah. Blumea 48:193-199. doi:10.3767/0006519 $03 \times 686178$

Hörger AC, Fones HN, Preston GM (2013) The current status of the elemental defense hypothesis in relation to pathogens. Front Plant Sci 4:395. doi:10.3389/fpls.2013.00395

Hughes AC (2017) Understanding the drivers of Southeast Asian biodiversity loss. Ecosphere 8(1):e01624. doi:10.1002/ecs2.1624

Isnard S, L'Huillier L, Rigault F, Jaffré T (2016) How did the ultramafic soils shape the flora of the New Caledonian hotspot? Plant Soil 403(1):53-76. doi:10.1007/s11104-016-2910-5

Jaffré T (1980) Etude écologique du peuplement végétal des sols dérivés de roches ultrabasiques en Nouvelle Calédonie. Coll. Trau. et Doc. ORSTOM 124

Jaffré $T$ (1992) Floristic and ecological diversity of the vegetation on ultramafic rocks in New Caledonia. In: Baker AJM, Proctor J, Reeves RD (eds) The vegetation of ultramafic (serpentine) soils: proceedings of the first international conference on serpentine ecology. Intercept Ltd., Andover

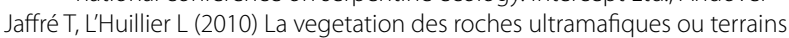
miniers. In: L'Huillier L, Jaffré T, Wulf A (eds) Mines et environnement en Nouvelle-Calédonie: les milieux sur substrats ultramafiques et leur restauration. IAC Ed, Noumea

Jaffré T, Munzinger J, Lowry PP II (2010) Threats to the conifer species found on New Caledonia's ultramafic massifs and proposals for urgently needed measures to improve their protection. Biodivers Conserv 19:1485-1502. doi:10.1007/s10531-010-9780-6

Jaffré T, Pillon Y, Thomine S, Merlot S (2013) The metal hyperaccumulators from New Caledonia can broaden our understanding of nickel accumulation in plants. Front Plant Sci 4:279. doi:10.3389/fpls.2013.00279 
Jepson Flora Project (eds) (2016) Jepson eFlora, http://ucjeps.berkeley.edu/ IJM.html. Accessed 14 Oct 2016

Jones DT, Rahman H, Bignell DE, Prasetyo AH (2010) Forests on ultramaficderived soils in borneo have very depauperate termite assemblages. $J$ Trop Ecol 26:103-114. doi:10.1017/S0266467409990356

Kay KM, Ward KL, Watt LR, Schemske DW (2011) Plant speciation. In: Harrison SP, Rajakaruna N (eds) Serpentine: evolution and ecology in a model system. University of California Press, Berkeley

Kazakou E, Dimitrakopoulos PG, Baker AJM, Reeves RD, Troumbis AY (2008) Hypotheses, mechanisms and trade-offs of tolerance and adaptation to ultramafic soils: from species to ecosystem level. Biol Rev 83:495-508. doi:10.1111/j.1469-185X.2008.00051.X

Kfayatullah Q, Shah MT, Arfan M (2001) Biogeochemical and environmental study of the chromite-rich ultramafic terrain of Malakand area, Pakistan. Environ Geol 40:1482-1486. doi:10.1007/s002540100374

Kien CN, Noi NV, Son LT, Ngoc HM, Tanaka S, Nishina T, Iwasaki K (2010) Heavy metal contamination of agricultural soils around a chromite mine in Vietnam. Soil Sci Plant Nutr 56:344-356. doi:10.1111/j.1747-0765.2010.00451.x

Kier G, Mutke J, Dinerstein E, Ricketts TH, Küper W, Kreft H, Barthlott W (2005) Global patterns of plant diversity and floristic knowledge. J Biogeogr 32:1107-1116. doi:10.1111/j.1365-2699.2005.01272.x

Kierczak J, Neel C, Bril H, Puziewicz J (2007) Effect of mineralogy and pedoclimatic variations on $\mathrm{Ni}$ and $\mathrm{Cr}$ distribution in serpentine soils under temperate climate. Geoderma 142:165-177. doi:10.1016/j. geoderma.2007.08.009

Kitayama K (1992) An altitudinal transect study of the vegetation on Mount Kinabalu, Borneo. Vegetatio 102:149-171. doi:10.1007/BF00044731

Kolář F, Fér T, Štech M, Trávníček P, Dušková E, Schönswetter P, Suda J (2012) Bringing together evolution on serpentine and polyploidy: spatiotemporal history of the diploid-tetraploid complex of Knautia arvensis (Dipsacaceae). PLoS ONE 7(7):e39988. doi:10.1371/journal.pone.0039988

Krämer U (2010) Metal hyperaccumulation in plants. Annu Rev Plant Biol 61:517-534. doi:10.1146/annurev-arplant-042809-112156

Kruckeberg AR (1954) The ecology of serpentine soils: a symposium. III. Plant species in relation to serpentine soils. Ecology 35:267-274

Kruckeberg AR (2002) Geology and plant life: the effects of landforms and rock type on plants. University of Washington Press, Seattle

Kumarathilaka P, Oze C, Vithanage V (2016) Perchlorate mobilization of metals in serpentine soils. Appl Geochem. doi:10.1016/j. apgeochem.2016.10.009

Lau JA, McCall AC, Davies KF, McKay JF, Wright JW (2008) Herbivores and edaphic factors constrain the realized niche of a native plant. Ecology 89:754-762. doi:10.1890/07-0591

Leakey RJG, Proctor J (1987) Invertebrates in the litter and soil at a range of altitudes on Gunung Silam, a small ultrabasic mountain in Sabah. J Trop Ecol 3:119-129

Lee WG (1992) The serpentinized areas of New Zealand, their structure and ecology. In: Roberts BA, Proctor J (eds) The ecology of areas with serpentinized rocks: a world view. Kluwer, Dordrecht

Linthout K, Helmers H (1994) Pliocene obducted, rotated and migrated ultramafic rocks and obduction-induced anatectic granite, SW Seram and Ambon, Eastern Indonesia. J Southeast Asian Earth Sci 9:95-109

Ma Y, Rajkumar M, Rocha I, Oliveira RS, Freitas H (2015) Serpentine bacteria influence metal translocation and bioconcentration of Brassica juncea and Ricinus communis grown in multi-metal polluted soils. Front Plant Sci 5:757. doi:10.3389/fpls.2014.00757

MacDonald AS, Barr SM (1984) The Nan River mafic-ultramafic belt, northern Thailand: geochemistry and tectonic significance. Bull Geol Soc Malays 17:209-224

Mandal A, Mohanty WK, Prakash S, Sharma SP, Gupta S (2015) Laterite covered mafic-ultramafic rocks: potential target for chromite exploration-a case study from southern part of Tangarparha, Odisha. J Geol Soc India 86:519-529. doi:10.1007/s12594-015-0342-0

Meindl GA, Bain DJ, Ashman TL (2013) Edaphic factors and plant-insect interactions: direct and indirect effects of serpentine soil on florivores and pollinators. Oecologia 173:1355-1366. doi:10.1007/s00442-013-2711-y

Mesjasz-Przybylowicz J, Przybylowicz W, Barnabas A, van der Ent A (2015) Extreme nickel hyperaccumulation in the vascular tracts of the tree Phyllanthus balgooyi from Borneo. New Phytol 209:1513-1526. doi:10.1111/nph.13712
Ministry of Environment and Renewable Energy (2012) The National Red List 2012 of Sri Lanka; Conservation status of the fauna and flora. Ministry of Environment, Colombo. http://www.environmentmin.gov.lk/web/ index.php?option=com_content\&view=article\&id $=175 \& l$ temid $=291$ \&lang=en. Accessed 24 Mar 2014

Mishra S, Das AP, Seragadam P (2009) Microbial remediation of hexavalent chromium from chromite contaminated mines of Sukinda Valley, Orissa (India). J Environ Res Dev 3:1122-1127

Mitra S (1973) Olivines from Sukinda ultramafites and the nature of the parental magma. N Jb Miner Mh 2:177-189

Mittermeier RA et al (2005) Hotspots revisited. Earth's biologically richest and most endangered terrestrial ecoregions. University of Chicago Press, Chicago

MOE (2012) The National Red List 2012 of Sri Lanka; Conservation status of the fauna and flora. Ministry of Environment, Colombo

Mohanty M, Pattnaik MM, Mishra AK, Patra HK (2011) Chromium bioaccumulation in rice grown in contaminated soil and irrigated mine wastewater-a case study at South Kaliapani chromite mine area, Orissa, India. Int J Phytoremediat 13:297-409. doi:10.1080/15226511003753979

Mohanty M, Pattnaik MM, Mishra AK, Patra HK (2012) Bio-concentration-an in situ phytoremediation study at South Kaliapani chromite mining area of Orissa, India. Environ Monit Assess 184:1015-1024. doi:10.1007/ s10661-011-2017-7

Moores EM (2011) Serpentinites and other ultramafic rocks: why they are important for Earth's history and possibly for its future. In: Harrison SP, Rajakaruna N (eds) Serpentine: evolution and ecology in a model system. University of California Press, Berkeley

Morel J-L, Echevarria G, Goncharova N (eds) (2006) Phytoremediation of metalcontaminated soils. Springer, Dordrecht

Munasinghe T, Dissanayake CB (1980) Is the Highland eastern Vijayan boundary in Sri Lanka a possible mineralized belt? Econ Geol 75:775-777. doi:10.2113/gsecongeo.75.5.774

Murren CJ, Douglass L, Gibson A, Dudash MR (2006) Individual and combined effects of $\mathrm{Ca} / \mathrm{Mg}$ ratio and water on trait expression in Mimulus guttatus. Ecology 87:2591-2602. doi:10.1890/0012-9658(2006)87[2591:IAC $\mathrm{EOM}] 2.0 \cdot \mathrm{CO} ; 2$

Naseem S, Bashir E, Shireen K, Shafiq S (2009) Soil-plant relationship of Pteropyrum olivieri, a ultramafic flora of Wadh, Balochistan, Pakistan and its use in mineral prospecting. Geologia 54:33-39. doi:10.5038/1937-8602.54.2.7

Neilson S, Rajakaruna N (2014) Phytoremediation of agricultural soils: using plants to clean metal-contaminated arable lands. In: Ansari AA, Gill SS, Lanza GR, Newman L (eds) Phytoremediation: management of environmental contaminants. Springer International Publishing, Switzerland

Netty S, Wardiyati T, Handayanto E, Maghfoer MD (2012) Nickel accumulating plants in the post-mining land of Sorowako, South Sulawesi, Indonesia. J Trop Agric 50:45-48

New Zealand Plant Conservation Network (2016) http://www.nzpcn.org.nz/. Accessed 13 Oct 2016

Ningthoujama PS, Dubeya CS, Guillotb S, Fagionb A-S, Shuklaa DP (2012) Origin and serpentinization of ultramafic rocks of Manipur Ophiolite Complex in the Indo-Myanmar subduction zone, Northeast India. J Asian Earth Sci 50:128-140. doi:10.1016/j.jseaes.2012.01.004

O'Dell RE (2014) Conservation and restoration of chemically extreme edaphic endemic flora in the Western US. In: Rajakaruna N, Boyd RS, Harris TB (eds) Plant ecology and evolution in harsh environments. Nova Science Publishers, Hauppauge

O'Dell RE, Claassen VP (2011) Restoration and revegetation of harsh soils. In: Harrison SP, Rajakaruna N (eds) Serpentine: the evolution and ecology of a model system. University of California Press, Berkeley

O'Dell RE, Rajakaruna N (2011) Intraspecific variation, adaptation, and evolution. In: Harrison SP, Rajakaruna N (eds) Serpentine: evolution and ecology in a model system. University of California Press, Berkeley

Orberger B, Lorand JP, Girardeau J, Mercier JCC, Pitragool S (1995) Petrogenesis of ultramafic rocks and associated chromitites in the Nan Uttaradit ophiolite, Northern Thailand. Lithos 35:153-182. doi:10.1016/0024-4937(94)00041-Y

Pal A, Paul AK (2012) Accumulation of polyhydroxyalkanoates by rhizobacteria underneath nickel-hyperaccumulators from ultramafic ecosystem. J Polym Environ 20:10-16. doi:10.1007/s10924-011-0355-8 
Pal A, Choudhuri P, Dutta S, Mukherjee PK, Paul AK (2004) Isolation and characterization of nickel-resistant microflora from ultramafic soils of Andaman. World J Microbiol Biotechnol 20:881-886. doi:10.1007/ s11274-004-2776-1

Pal A, Dutta S, Mukherjee PK, Paul AK (2005) Occurrence of heavy metal-resistance in microflora from ultramafic soil of Andaman. J Basic Microbiol 45:207-218. doi:10.1002/jobm.200410499

Pal A, Ghosh S, Paul AK (2006) Biosorption of cobalt by fungi from ultramafic soil of Andaman. Bioresour Technol 97:1253-1258. doi:10.1016/j. biortech.2005.01.043

Pal A, Wauters G, Paul AK (2007) Nickel tolerance and accumulation by bacteria from rhizosphere of nickel hyperaccumulators in serpentine soil ecosystem of Andaman, India. Plant Soil 293:37-48. doi:10.1007/ s11104-007-9195-7

Palm ER, Van Volkenburgh E (2014) Physiological adaptations of plants to serpentine soils. In: Rajakaruna N, Boyd RS, Harris TB (eds) Plant ecology and evolution in harsh environments. Nova Science Publishers, Hauppauge

Parry DE (1985) Ultramafic soils in the humid tropics with particular reference to Indonesia. Unpublished report of Hunting Technical Services Ltd., Taupo

Peng Cl, Lin CW, Rimi R, Kono Y, Leong W, Chung KF (2015) Two new species of Begonia, B. moneta and B. peridoticola (Begoniaceae) from Sabah, Malaysia. Bot Stud 56:7. doi:10.1186/s40529-015-0087-5

Peucker-Ehrenbrink B, Miller MW (2004) Quantitative bedrock geology of east and Southeast Asia (Brunei, Cambodia, eastern and southeastern China, East Timor, Indonesia, Japan, Laos, Malaysia, Myanmar, North Korea, Papua New Guinea, Philippines, far-eastern Russia, Singapore, South Korea, Taiwan, Thailand, Vietnam). Geochem Geophys. doi:10.1029/200 $3 \mathrm{GC000619}$

Pillon Y (2012) Time and tempo of diversification in the flora of New Caledonia. Bot J Linn Soc 170:288-298. doi:10.1111/j.1095-8339.2012.01274.x

Pillon Y, Munzinger J, Amir H, Lebrun M (2010) Ultramafic soils and species sorting in the flora of New Caledonia. J Ecol 98:1108-1116. doi:10.1111/j.1365-2745.2010.01689.x

Pollard AJ, Reeves RD, Baker AJM (2014) Facultative hyperaccumulation of heavy metals and metalloids. Plant Sci 217-218:8-17. doi:10.1016/j. plantsci.2013.11.011

Prasad PRC, Reddy CS, Dutt CBS (2007) Phytodiversity assessment of tropical rainforest of North Andaman Islands, India. Res J For 1:27-39. doi:10.3923/rjf.2007.27.39

Proctor J (1992) The vegetation over ultramafic rocks in the tropical far east. In: Roberts BA, Proctor J (eds) The ecology of areas with serpentinised rocks. A world view. Kluwer Academic Publishers, Dordrecht

Proctor J (2003) Vegetation and soil and plant chemistry on ultramafic rocks in the tropical Far East. Perspect Plant Ecol Evol Syst 6:105-124. doi:10.1078/1433-8319-00045

Proctor J, Cole MM (1992) The ecology of ultramafic areas in Zimbabwe. In: The ecology of areas with serpentinized rocks. Springer Netherlands, Dordrecht, pp 313-331

Proctor J, Lee YF, Langley AM, Munro WR, Nelson T (1988a) Ecological studies on Gunung Silam, a small ultrabasic mountain in Sabah, Malaysia. I. Environment, forest structure and floristics. J Ecol 76:320-340

Proctor J, Howson G, Munro WRC, Robertson FM (1988b) Use of the cotton strip assay at 3 altitudes on an ultrabasic mountain in Sabah, Malaysia In: Harrison AF, Latter PM, Walton DWH (eds) Cotton strip assay: an index of decomposition in soils. Grange-over-Sands, NERC/ITE. (ITE Symposium, 24: 117-122)

Proctor J, Phillipps C, Duff DK, Heaney A, Robertson FM (1989) Ecological studies on Gunung Silam, a small ultrabasic mountain in Sabah, Malaysia. II. Some forest processes. J Ecol 77:317-331

Proctor J, van Balgooy MMJ, Fairweather FM, Nagy L, Reeves RD (1994) A preliminary re-investigation of a plant geographical 'El Dorado'. Trop Biodivers 2:303-316

Proctor J, Baker AJM, van Balgooy MMJ, Bruijnzeel LA, Jones SH, Madulid DA (1997) Mount Bloomfield, Palawan, the Philippines: the scrub and Gymnostoma woodland. In: Jaffré T, Reeves RD, Bacquer T (eds) The ecology of ultramafic and metalliferous areas. ORSTOM, New Caledonia

Proctor J, Argent GC, Madulid DA (1998) Forests of the ultramafic Mount Giting-Giting, Sibuyan Island, Philippines. Edinb J Bot 55:295-316
Proctor J, Bruijnzeel LA, Baker AJM (1999) What causes the vegetation types on Mount Bloomfield, a coastal tropical mountain of the western Philippines? Global Ecol Biogeogr 8:347-354. doi:10.1046/j.1365-2699.1999.00147.x

Proctor J, Baker AJM, Bruijnzeel LA, Van MMJ, Fairweather GM, Madulid DA (2000a) Foliar chemistry and leaf herbivory on Mount Bloomfield, Palawan, Philippines. Bot J Scotland 52:79-89. doi:10.1080/03746600008684946

Proctor J, Baker AJM, van Balgooy MMJ, Bruijnzeel LA, Jones SH, Madulid DA (2000b) Mount Bloomfield, Palawan, Philippines: forests on greywacke and serpentinized peridotite. Edinb J Bot 57:121-139

Quimado MO, Fernando ES, Trinidad LC, Doronila A (2015) Nickel hyperaccumulating species of Phyllanthus (Phyllanthaceae) from the Philippines. Aust J Bot 63:103-110. doi:10.1071/BT14284

Rajakaruna N (2004) The edaphic factor in the origin of species. Int Geol Rev 46:471-478

Rajakaruna N, Baker AJM (2004) Ultramafic: a model habitat for botanical research in Sri Lanka. Ceylon J Sci Biol Sci 32:1-19

Rajakaruna N, Bohm BA (2002) Ultramafic and its vegetation: a preliminary study from Sri Lanka. J Appl Bot Angew Bot 76:20-28

Rajakaruna N, Boyd RS (2008) The edaphic factor. In: Jorgensen SE, Fath B (eds) The encyclopedia of ecology, vol 2. Elsevier, Oxford

Rajakaruna N, Harris CS, Towers GHN (2002) Antimicrobial activity of plants collected from ultramafic outcrops in Sri Lanka. Pharm Biol 40:235-244

Rajakaruna N, Harris TB, Alexander EB (2009) Serpentine geoecology of eastern North America: a review. Rhodora 111:21-108. doi:10.3119/07-23.1

Rajakaruna N, Knudsen K, Fryday A, O'Dell RE, Pope N, Olday FC, Woolhouse S (2012) Investigation of the importance of rock chemistry for saxicolous lichen communities of the New Idria serpentinite mass, San Benito County, California, USA. Lichenologist 44:695-714. doi:10.1017/ S0024282912000205

Rajapaksha AU, Vithanage M, Oze C et al (2012) Nickel and manganese release in ultramafic soil from the Ussangoda ultramafic complex, Sri Lanka. Geoderma 189-190:1-9

Rajapaksha AU, Vithanage M, Ok YS, Oze C (2013) Cr(VI) formation related to $\mathrm{Cr}(\mathrm{III})$-muscovite and birnessite interactions in ultramafic environments. Environ Sci Technol 47:9722-9729. doi:10.1021/es4015025

Ranasinghe NS (1987) Serpentinites associated with the Precambrian of Sri Lanka. Geological Society of Sri Lanka special publication No. 3. Geological Survey Department, Colombo

Reeves RD (2003) Tropical hyperaccumulators of metals and their potential for phytoextraction. Plant Soil 249:57-65. doi:10.1023/A:1022572517197

Reeves R, Baker A, Borhidi A, Berazain R (1999) Nickel hyperaccumulation in the serpentine flora of Cuba. Ann Bot 83:1-10. doi:10.1006/ anbo.1998.0786

Safford HD, Harrison SP (2004) Fire effects on plant diversity in serpentine versus sandstone chaparral. Ecology 85:539-548. doi:10.1890/03-0039

Safford HD, Viers JH, Harrison SP (2005) Serpentine endemism in the California flora: a database of serpentine affinity. Madroño 52:222-257

Samantaray S, Rout GR, Das P (2001) Heavy metal and nutrient concentration in soil and plants growing on a metalliferous chromite minespoil. Environ Technol 22:1147-1154. doi:10.1080/09593332208618204

Sambatti JBM, Rice KJ (2006) Local adaptation, patterns of selection, and gene flow in the Californian serpentine sunflower (Helianthus exilis). Evolution 60:696-710. doi:10.1111/j.0014-3820.2006.tb01149.x

Samithri YAS (2015) Ecology of the serpentine vegetation at Ussangoda, Sri Lanka. M. Phil Thesis, University of Peradeniya, Sri Lanka

Sawada Y, Aiba S, Takyu M, Repin R, Nais J, Kitayama K (2015) Community dynamics over 14 years along gradients of geological substrate and topography in tropical montane forests on Mount Kinabalu, Borneo. J Trop Ecol 31:117-128. doi:10.1017/S0266467414000777

Schechter S, Branco S (2014) The ecology and evolution of mycorrhizal fungi in extreme soils. In: Rajakaruna N, Boyd RS, Harris TB (eds) Plant ecology and evolution in harsh environment. Nova Science Publishers, Hauppauge

Selby JP, Jeong AL, Toll K, Wright KM, Lowry DB (2014) Methods and discoveries in the pursuit of understanding the genetic basis of adaptation to harsh environments in Mimulus. In: Rajakaruna N, Boyd RS, Harris TB (eds) Plant ecology and evolution in harsh environments. Nova Science Publishers, Hauppauge 
Senevirathne AS, Nandadasa HG, Fernando WS, Sanjeevani, HHVM, Rajapakshe RLHR (2000) The serpentine vegetation of Ussangoda (Hambantota District) and nickel accumulating plant species. In: Proceedings of the Sixth Annual Forestry and Environmental Symposium, Kandy. http:// journals.sjp.ac.lk/index.php/fesympo/article/view/1430. Accessed 11 Oct 2016

Seneviratne M, Seneviratne G, Madawala HMSP, Iqbal MCM, Rajakaruna N, Vithanage M (2016a) A preliminary study of the role of bacterial-fungal co-inoculation on heavy metal phytotoxicity in serpentine soil. Aust J Bot 63:261-268. doi:10.1071/BT14270

Seneviratne M, Gunaratne S, Bandara T, Weerasundara L, Rajakaruna N, Madawala HMSP, Seneviratne G, Vithanage M (2016b) Plant growth promotion by Bradyrhizobium japonicum under heavy metal stress. S Afr J Bot 105:19-24. doi:10.1016/j.sajb.2016.02.206

Shah MT, Begum S, Khan S (2010) Pedo and biogeochemical studies of mafic and ultramafic rocks in the Mingora and Kabal areas, Swat, Pakistan. Environ Earth Sci 60:1091-1102. doi:10.1007/s12665-009-0253-8

Shah MT, Ara J, Muhammad S, Khan S, Asad SA, Ali L (2014) Potential heavy metals accumulation of indigenous plant species along the mafic and ultramafic terrain in the Mohmand Agency, Pakistan. Clean Soil Air Water 42:339-346. doi:10.1002/clen.201200632

Sheoran V, Sheoran AS, Poonia P (2009) Phytomining: a review. Miner Eng 22:1007-1019

Shi G, Harlow GE, Wang J, Wang J, Enoch NG, Wang X, Cao SM, Enyuancui W (2012) Mineralogy of jadeitite and related rocks from Myanmar: a review with new data. Eur J Mineral 24:345-370. doi:10.1127/0935-1221/2012/0024-2190

Sodhi NS, Koh LP, Brook BW, Ng PK (2004) Southeast Asian biodiversity: an impending disaster. Trends Ecol Evol 19:654-660. doi:10.1016/j. tree.2004.09.006

Sodhi NS, Posa MRC, Lee TM, Bickford D, Koh LP, Brook BW (2010) The state and conservation of Southeast Asian biodiversity. Biodivers Conserv 19:317-328. doi:10.1007/s10531-009-9607-5

Soibam I, Khuman MCH, Subhamenon SS (2015) Ophiolitic rocks of the IndoMyanmar Ranges, NE India: relicts of an inverted and tectonically imbricated hyper-extended continental margin basin? Geological Society, London, Special Publications, pp 413. doi: 10.1144/SP413.12

Southworth D, Tackaberry LE, Massicotte HB (2014) Mycorrhizal ecology on serpentine soils. Plant Ecol Divers 7:445-455. doi:10.1080/17550874.2013.848950

Spasojevic MJ, Damschen El, Harrison SP (2014) Patterns of seed dispersal syndromes on serpentine soils: examining the roles of habitat patchiness, soil infertility and correlated functional traits. Plant Ecol Divers 7:401-410. doi:10.1080/17550874.2012.678506

Springer YP (2009) Edaphic quality and plant-pathogen interactions: effects of soil calcium on fungal infection of a serpentine flax. Ecology 90:1852-1862. doi:10.1890/08-0740.1

Strauss SY, Boyd RS (2011) Herbivory and other cross-kingdom interactions on harsh soils. In: Harrison SP, Rajakaruna N (eds) Serpentine: the evolution and ecology of a model system. University of California Press, Berkeley

Strauss SY, Cacho NI (2013) Nowhere to run, nowhere to hide: the importance of enemies and apparency in adaptation to harsh soil environments. Am Nat 182(1):E1-E14. doi:10.1086/670754

Sugau JB, van der Ent A (2016) Pittosporum peridoticola (Pittosporaceae), a new ultramafic obligate species restricted to Kinabalu Park (Sabah, Malaysia). Bot Stud 57:4. doi:10.1186/s40529-016-0119-9

Tan BK, Khoo TT (1993) Clinopyroxene composition and tectonic setting of the Bentong-Raub belt, Peninsular Malaysia. J Southeast Asian Earth Sci 8:539-545

Tashakor M, Yaacob WZW, Mohamad H (2011) Speciation and availability of Cr, $\mathrm{Ni}$ and $\mathrm{Co}$ in ultramafic soils of Ranau, Sabah. Am J Geosci 2:4-9

Tashakor M, Yaacob WZW, Mohamad H (2013) Ultramafic soils, adverse habitat for plants: case study at Peninsular. Am J Environ Sci 9:82-87

Tennakoon K, Senevirathna MKI, Kehelpannala KVW (2007) Extraction of pure metallic nickel from ores and plants at Ussangoda, Sri Lanka. J Natl Sci Found 35:245-250

Thanh NX, Hai TT, Hoang N, Lan VQ et al (2014) Backarc mafic-ultramafic magmatism in Northeastern Vietnam and its regional tectonic significance. J Asian Earth Sci 90:45-60. doi:10.1016/j.jseaes.2014.04.001
Thomas L, Proctor J (1997) Invertebrates in the litter and soil on the ultramafic Mount Giting-Giting, Philippines. J Trop Ecol 13:125-131. doi:10.1017/ S0266467400010300

Thorne JH, Huber PR, Harrison SP (2011) Systematic conservation planning: Protecting rarity, representation, and connectivity in regional landscapes. In: Harrison SP, Rajakaruna N (eds) Serpentine: evolution and ecology in a model system. University of California Press, Berkeley

Turner TL, Bourne EC, Von Wettberg EJ, Hu TT, Nuzhdin SV (2010) Population resequencing reveals local adaptation of Arabidopsis lyrata to serpentine soils. Nat Genet 42:260-263. doi:10.1038/ng.515

Tylko G, Mesjasz-Przybyłowicz J, Przybyłowicz WJ (2007) X-ray microanalysis of biological material in the frozen-hydrated state by PIXE. Microsc Res Tech 70:55-68

UNESCO 2016. UNESCO Global Geoparks. http://www.unesco.org/new/en/ natural-sciences/environment/earth-sciences/unesco-global-geoparks/. Accessed 27 Oct 2016

Vallano DM, Selmants PC, Zavaleta ES (2012) Simulated nitrogen deposition enhances the performance of an exotic grass relative to native ultramafic grassland competitors. Plant Ecol 213:1015-1026. doi:10.1007/ s11258-012-0061-1

Van Balgooy MMJ and Tantra IGM (1986) The vegetation in two areas in Sulawesi, Indonesia, pp 1-61. Buletin Penelitian Hutan Special edition

Van der Ent A, Mulligan D (2015) Multi-element concentrations in plant parts and fluids of malaysian nickel hyperaccumulator plants and some economic and ecological considerations. J Chem Ecol 41:396-408. doi:10.1007/s10886-015-0573-y

Van der Ent A, Reeves RD (2015) Foliar metal accumulation in plants from copper-rich ultramafic outcrops: case studies from Malaysia and Brazil. Plant Soil 389:401-418. doi:10.1007/s11104-015-2385-9

Van der Ent A, Vanijajiva O (2014) Gynura tambuyukonensis (Asteraceae), an obligate ultramafic species endemic to Mount Tambuyukon (Kinabalu Park, Sabah, Malaysia). Phytotaxa 158:291-296. doi:10.11646/ phytotaxa.158.3.9

Van der Ent A, Wong KM (2015) Range extension of Christisonia scortechinii from mainland Southeast Asia into Borneo, and notes on the distinction between Aeginetia and Christisonia (Orobanchaceae). Bot Stud 56:28. doi:10.1186/s40529-015-0109-3

Van der Ent A, Wood JJ (2012) Mount Tambuyukon —an intriguing mountain and its orchids. Malesian Orchid J 10:102-122

Van der Ent A, Wood JJ (2013) Orchids of extreme serpentinite (ultramafic) habitats in Kinabalu Park. Males Orchid J 12:39-54

Van der Ent A, Baker AJM, van Balgooy MMJ, Tjoa A (2013a) Ultramafic nickel laterites in Indonesia (Sulawesi, Halmahera): mining, nickel hyperaccumulators and opportunities for phytomining. J Geochem Explor 128:72-79. doi:10.1016/j.gexplo.2013.01.009

Van der Ent A, Baker AJM, Reeves RD, Pollard AJ, Schat H (2013b) Hyperaccumulators of metal and metalloid trace elements: facts and fiction. Plant Soil 362:319-334. doi:10.1007/s11104-012-1287-3

Van der Ent A, Mulligan DR, Erskine P (2013b) Discovery of nickel hyperaccumulators from Kinabalu Park, Sabah (Malaysia) for potential utilization in phytomining. In: Paper presented at environment 2013: 3rd international seminar on environmental issues in mining. Proceedings. Santiago, Chile December 4-6

Van der Ent A, Repin R, Sugau J, Wong KM (2014) The ultramafic flora of Sabah: an introduction to the plant diversity on ultramafic soils. Natural History Publications (Borneo), Kota Kinabalu

Van der Ent A, Wong KM, Sugau J, Repin R (2015a) Plant diversity and ecology of ultramafic outcrops in Sabah (Malaysia). Aust J Bot 63:204-215. doi:10.1071/BT14214

Van der Ent A, Sumail S, Clarke C (2015b) Habitat differentiation of obligate ultramafic Nepenthes endemic to Mount Kinabalu and Mount Tambuyukon (Sabah, Malaysia). Plant Ecol 216:789-807. doi:10.1007/ s11258-015-0468-6

Van der Ent A, Rajakaruna R, Boyd RS, Echevarria G, Repin R, Williams D (2015c) Global research on ultramafic (serpentine) ecosystems (8th international conference on serpentine ecology in Sabah, Malaysia): a summary and synthesis. Aust J Bot 63:1-16. doi:10.1071/BT15060

Van der Ent A, Jaffré T, L'Huillier L, Gibson N, Reeves RR (2015d) The flora of ultramafic soils in the Australia-Pacific Region: state of knowledge and research priorities. Aust J Bot 63:173-190. doi:10.1071/BT15038 
Van der Ent A, Baker AJM, Reeves RD, Pollard AJ, Schat H (2015e) Commentary: toward a more physiologically and evolutionarily relevant definition of metal hyperaccumulation in plants. Front Plant Sci 6:554. doi:10.3389/ fpls.2015.00554

Van der Ent A, Erskine PD, Sumail S (2015f) Ecology of nickel hyperaccumulator plants from ultramafic soils in Sabah (Malaysia). Chemoecology 25:243-259. doi:10.1007/s00049-015-0192-7

Van der Ent A, Baker AJM, Reeves RD, Chaney RL, Anderson C, Meech J, Erskine PD, Simonnot M-O, Vaughan J, Morel J-L, Echevarria G, Fogliani B, Mulligan D (2015g) 'Agromining': farming for metals in the future? Environ Sci Technol 49:4773-4780. doi:10.1021/es506031u

Van der Ent A, Erskine PD, Mulligan DR, Repin R, Karim R (2016a) Vegetation on ultramafic edaphic islands in Kinabalu Park (Sabah, Malaysia) in relation to soil chemistry and altitude. Plant Soil 403(1):77-101. doi:10.1007/ s11104-016-2859-4

Van der Ent A, Echevarria G, Tibbett M (2016b) Delimiting soil chemistry thresholds for nickel hyperaccumulator plants in Sabah (Malaysia). Chemoecology 26:67-82. doi:10.1007/s00049-016-0209-x

Van der Ent A, Van Balgooy MMJ, Van Welzen P (2016c) Actephila alanbakeri (Phyllanthaceae): a new nickel hyperaccumulating species from localised ultramafic soils in Sabah (Malaysia). Bot Stud 57(1):6. doi:10.1186/ s40529-016-0122-1

Venter A, Levanets A, Siebert S, Rajakaruna N (2015) A preliminary survey of the diversity of soil algae and cyanoprokaryotes on mafic and ultramafic substrates in South Africa. Aust J Bot 63:341-352. doi:10.1071/ BT14207

Visioli G, Marmiroli N (2013) The proteomics of heavy metal hyperaccumulation by plants. J Proteom 79:133-145. doi:10.1016/j.jprot.2012.12.006

Vithanage M, Rajapaksha AU, Oze C, Rajakaruna N, Dissanayake CB (2014) Metal release from serpentine soils in Sri Lanka. Environ Monit Assess 186(6):3415-3429. doi:10.1007/s10661-014-3626-8

Von Wettberg EJ, Wright JW (2011) Genomic approaches to understanding adaptation. In: Harrison SP, Rajakaruna N (eds) Serpentine: the evolution and ecology of a model system. University of California Press, Berkeley

Von Wettberg EJ, Ray-Mukherjee J, D'Adesky N, Nesbeth D, Sistla S (2014) The evolutionary ecology and genetics of stress resistance syndrome (SRS) traits: revisiting Chapin, Autumn and Pugnaire (1993). In: Rajakaruna N Boyd RS, Harris TB (eds) Plant ecology and evolution in harsh environments. Nova Science Publishers, Hauppauge

Weerasinghe HAS, labal MCM (2011) Plant diversity and soil characteristics of the Ussangoda ultramafic site. J Natl Sci Found 39:355-363
Weiss SB (1999) Cars, cows, and checkerspot butterflies: nitrogen deposition and management of nutrient-poor grasslands for a threatened species. Conserv Biol 13:1476-1486

Wells K, Lakim MB, Schulz S, Ayasse M (2011) Pitchers of Nepenthes rajah collect faecal droppings from both diurnal and nocturnal small mammals and emit fruity odour. J Trop Ecol 27:347-353. doi:10.1017/ S0266467411000162

Whiting SN, Reeves RD, Richards D, Johnson MS et al (2004) Research priorities for conservation of metallophyte biodiversity and their potential for restoration and site remediation. Restor Ecol 12:106-116. doi:10.1111/j.1061-2971.2004.00367.x

Wild H (1965) The flora of the Great Dyke of southern Rhodesia with special reference to the serpentine soils. Kirkia 5:49-86

Wither ED, Brooks RR (1977) Hyperaccumulation of nickel by some plants of South-East Asia. J Geochem Explor 8:579-583. doi:10.1016/0375-6742(77)90100-5

Wolf A (2001) Conservation of endemic plants in ultramafic landscapes. Biol Conserv 100:35-44. doi:10.1016/S0006-3207(00)00205-6

Wolf A, Thorp RW (2011) Plant-pollinator interactions in naturally fragmented habitats. In: Harrison SP, Rajakaruna N (eds) Serpentine: evolution and ecology in a model system. University of California Press, Berkeley

Wong KM, van der Ent A (2014) Eriobotrya balgooyi (Rosaceae), a new obligate ultramafic endemic from Kinabalu Park, Borneo. Plant Ecol Evol 147:134-140. doi:10.5091/plecevo.2014.938

Wood JJ, van der Ent A (2012) Mount Tambuyukon - an intriguing mountain and its orchids. Malesian Orchid J 10:103-122

Wright JW, Stanton ML (2011) Local adaptation in heterogeneous landscapes: reciprocal transplant experiments and beyond. In: Harrison SP, Rajakaruna N (eds) Serpentine: evolution and ecology in a model system. University of California Press, Berkeley

Wu CA, Lowry DB, Cooley AM, Wright KM, Lee YW, Willis JH (2008) Mimulus is an emerging model system for the integration of ecological and genomic studies. Heredity 100(2):220-230. doi:10.1038/sj.hdy.6801018

Wu C, Lowry D, Nutter L, Willis J (2010) Natural variation for drought-response traits in the Mimulus guttatus species complex. Oecologia 162:23-33. doi:10.1007/s00442-009-1448-0

\section{Submit your manuscript to a SpringerOpen ${ }^{\circ}$ journal and benefit from:}

- Convenient online submission

- Rigorous peer review

- Immediate publication on acceptance

- Open access: articles freely available online

- High visibility within the field

- Retaining the copyright to your article

Submit your next manuscript at springeropen.com 